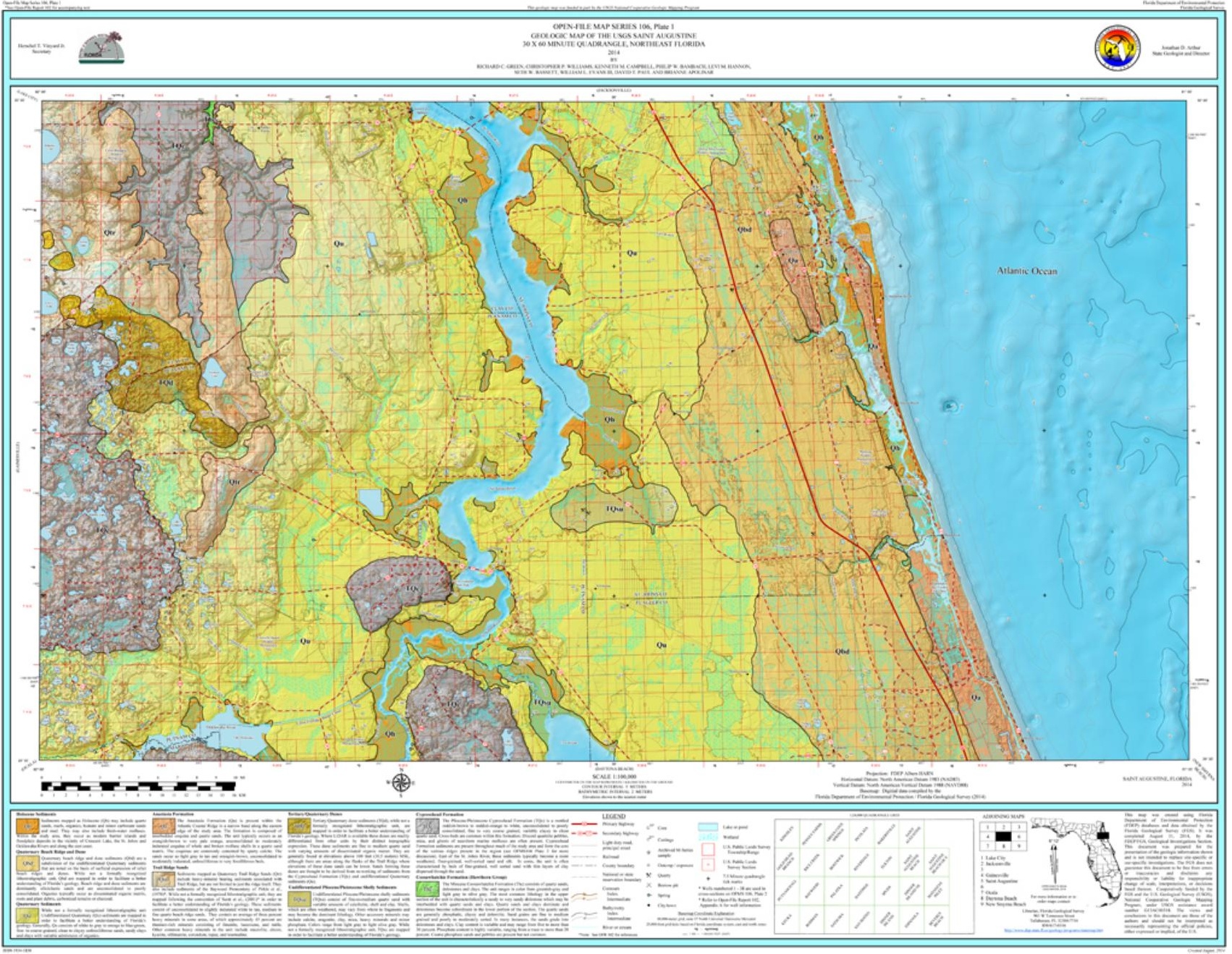




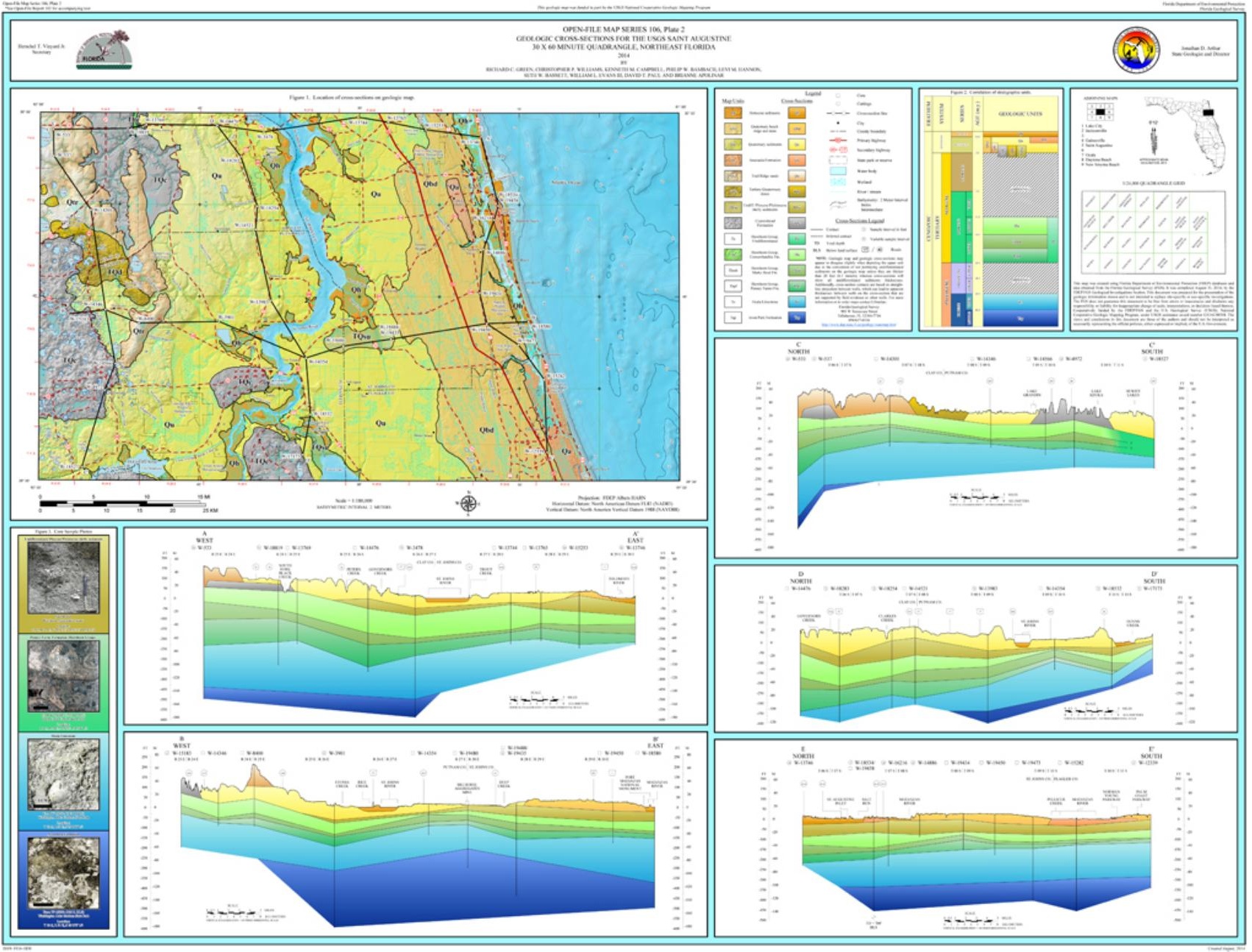




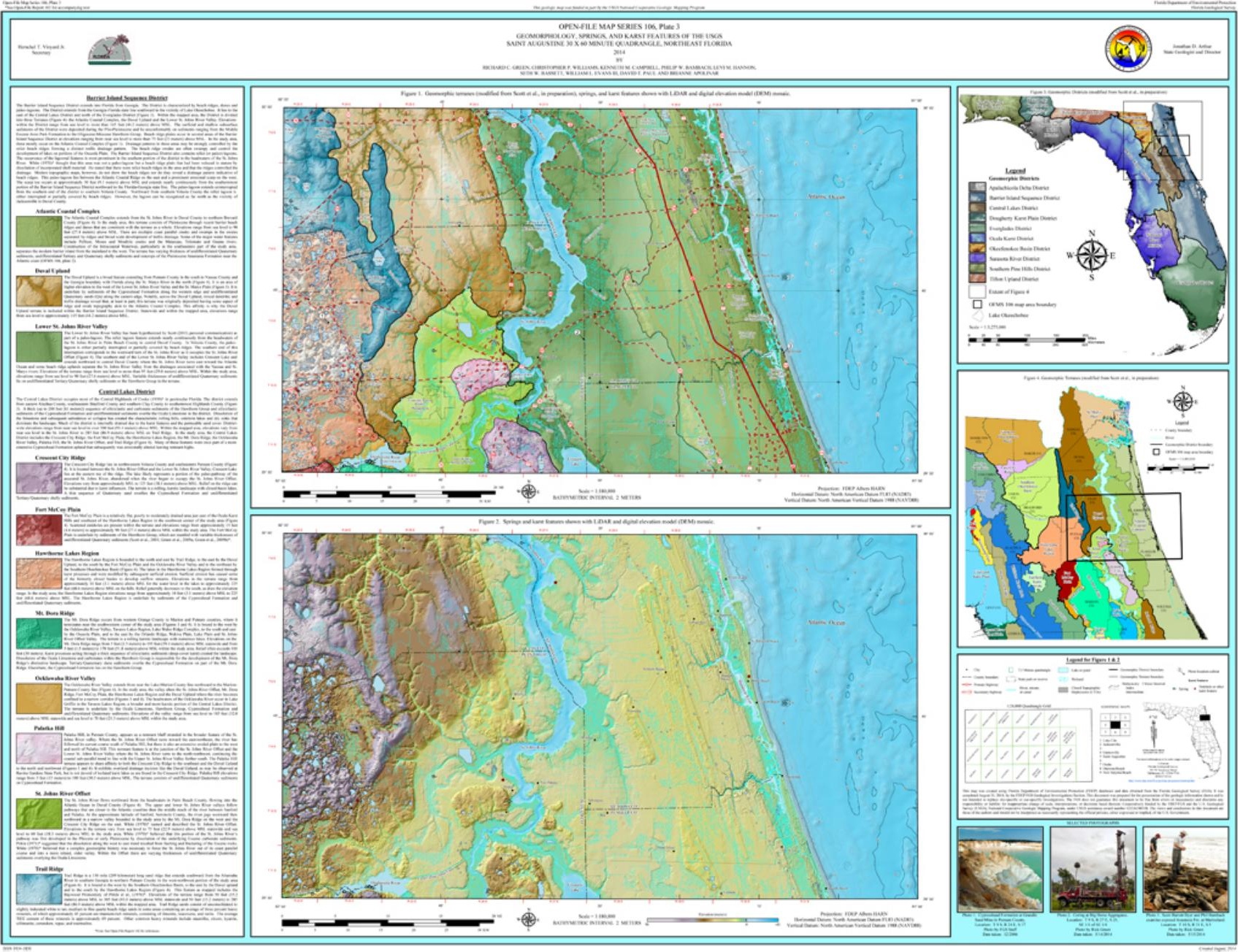




\section{STATE OF FLORIDA}

\section{DEPARTMENT OF ENVIRONMENTAL PROTECTION}

Herschel T. Vinyard Jr., Secretary

\section{REGULATORY PROGRAMS}

Cliff Wilson, Deputy Secretary

\section{FLORIDA GEOLOGICAL SURVEY}

Jonathan D. Arthur, State Geologist and Director
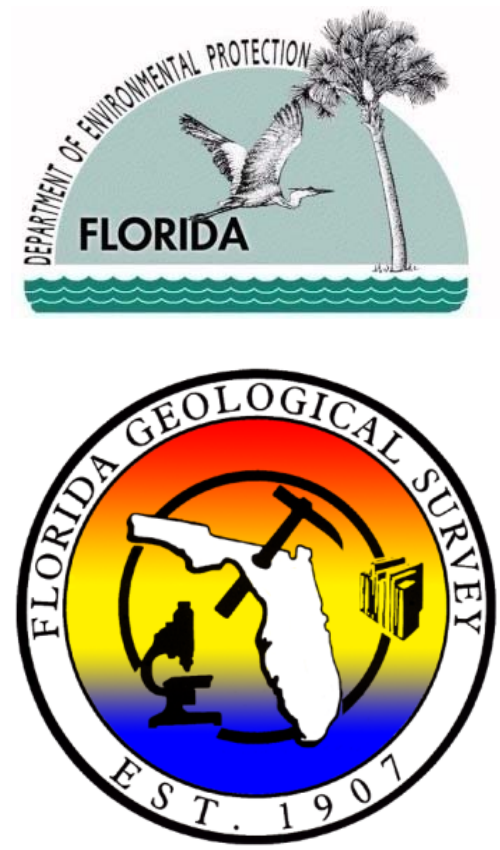

OPEN-FILE REPORT 102

Text to accompany geologic map of the USGS Saint Augustine 30 x 60 minute quadrangle, Northeast Florida (Open-File Map Series 106)

By

Richard C. Green, Christopher P. Williams, Kenneth M. Campbell, Philip W. Bambach, Levi M. Hannon, Seth W. Bassett, William L. Evans III, Brianne Apolinar and David T. Paul

This geologic map was funded in part by the USGS National Cooperative Geologic Mapping Program under assistance award number G13AC00318 in Federal fiscal year 2013 



\section{TABLE OF CONTENTS}

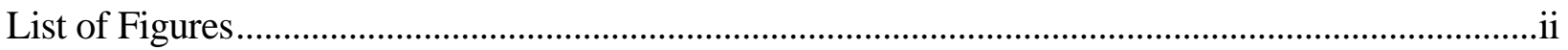

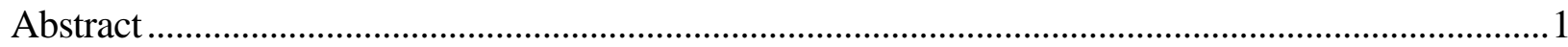

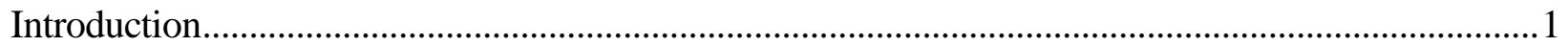

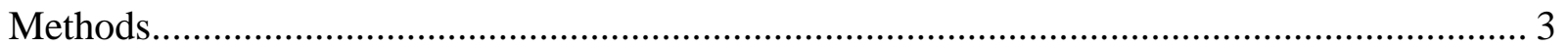

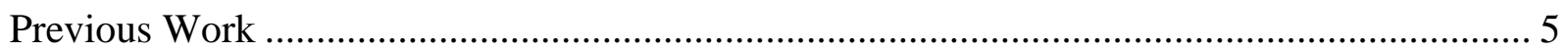

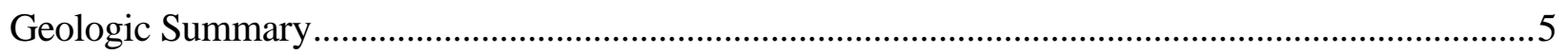

Structure

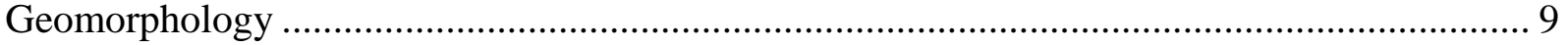

Barrier Island Sequence District ........................................................................ 10

Atlantic Coastal Complex ......................................................................................... 10

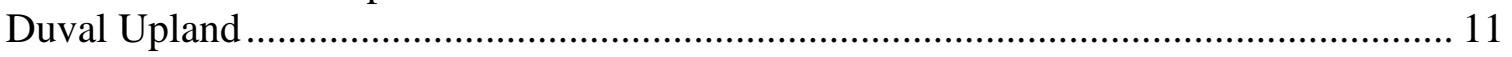

Lower St. Johns River Valley ………………………............................................ 11

Central Lakes District .................................................................................................. 11

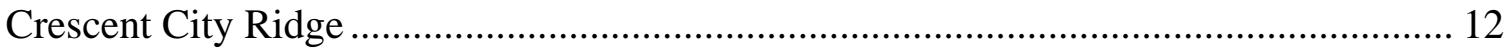

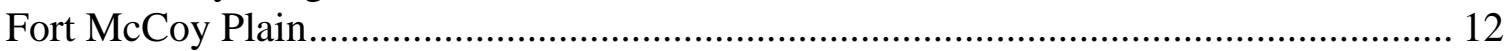

Hawthorne Lakes Region.......................................................................................... 12

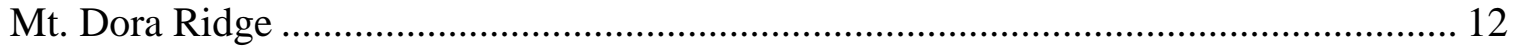

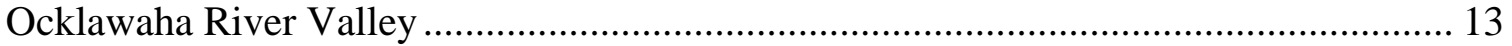

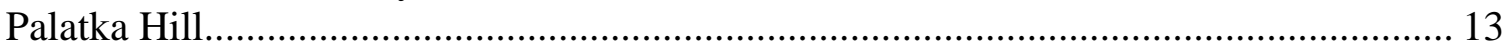

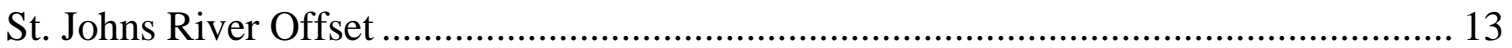

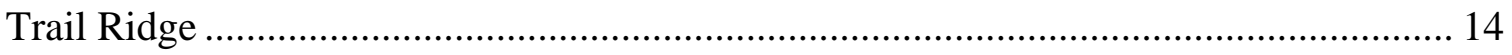

Lithostratigraphic Units .......................................................................................................14

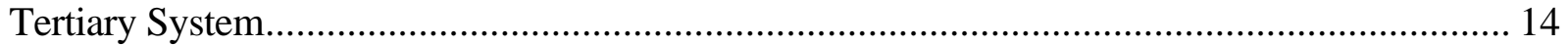

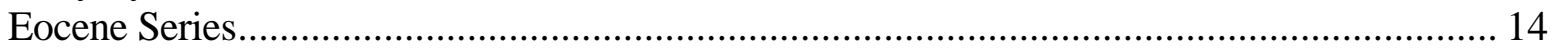

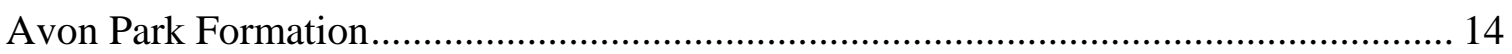

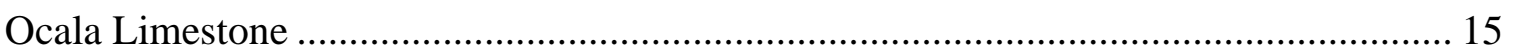

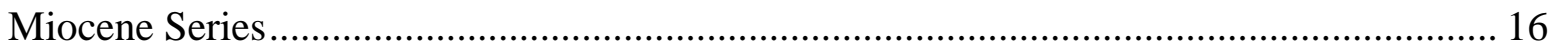

Hawthorn Group ………………………………………..................................... 16

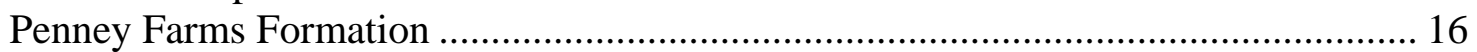

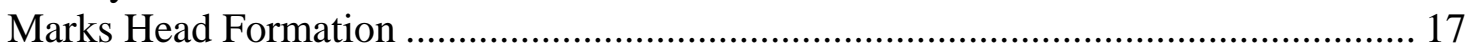

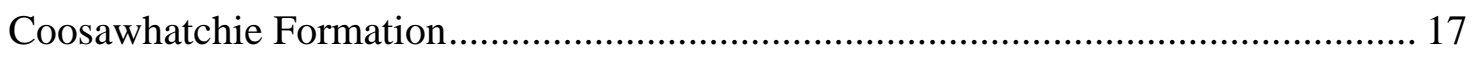

Hawthorn Group (Undifferentiated) …………………............................................. 18

Tertiary/Quaternary Systems....................................................................................... 18

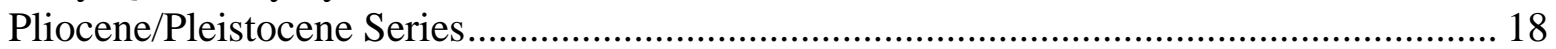

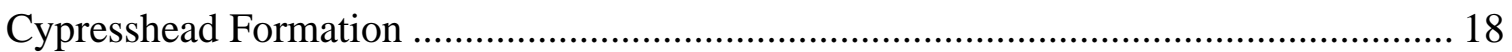

Pliocene/Pleistocene Shelly Sediments................................................................... 19

Tertiary/Quaternary Dunes ....................................................................................... 20

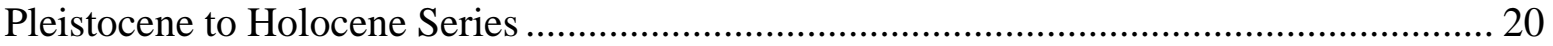

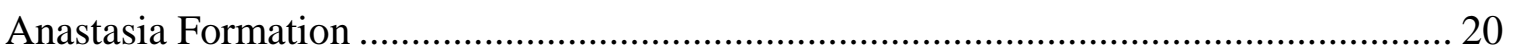




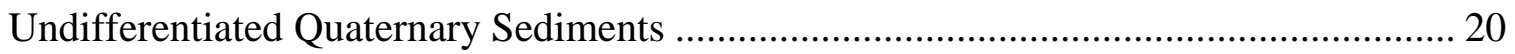

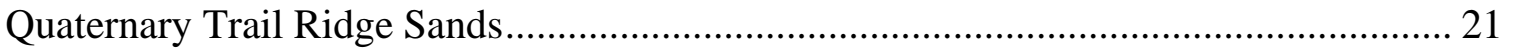

Quaternary Beach Ridge and Dune............................................................................. 21

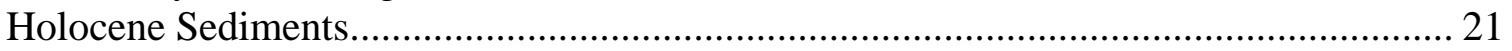

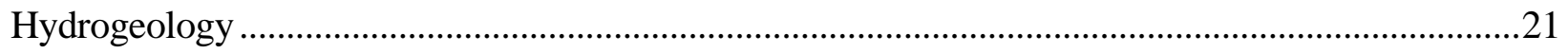

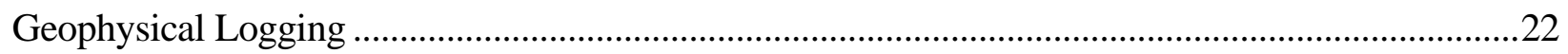

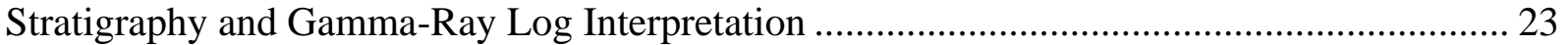

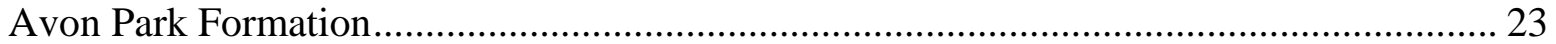

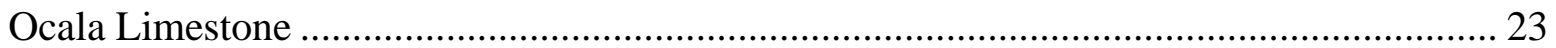

Hawthorn Group .............................................................................................. 23

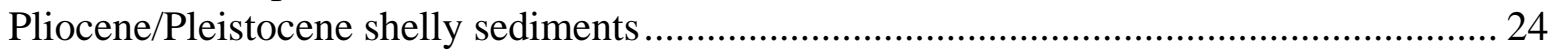

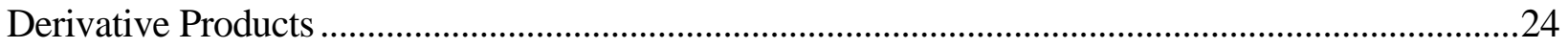

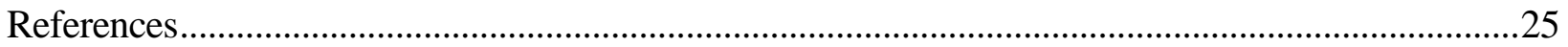

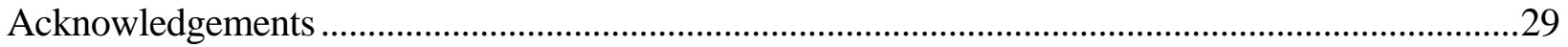

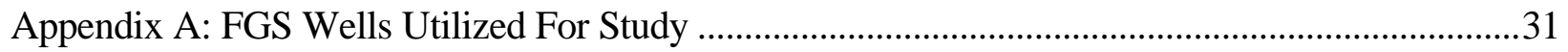

\section{LIST OF FIGURES}

Figure 1. Nearby areas mapped under the FGS STATEMAP Program.................................... 2

Figure 2. FGS cores (squares), cuttings (circles) and St. Johns River Water Management District geophysical logs (triangles) utilized for top of rock models.................................................. 4

Figure 3. Location of selected river basins, springs and other water bodies. ............................. 6

Figure 4. Principal subsurface structures of north Florida (modified from Scott, 1988).............. 8

Figure 5. Terraces in the study area (after Healy, 1975). ................................................... 9

Figure 6. Gamma Log of W-19480 (see OFMS 106, plate 2, Cross-Section B-B') ................... 22 
OPEN-FILE REPORT 102

\title{
Text to accompany geologic map of the USGS Saint Augustine 30 x 60 minute quadrangle, Northeast Florida (Open File Map Series 106)
}

Richard C. Green (P.G. No. 1776), Christopher P. Williams, Kenneth M. Campbell, Philip W. Bambach, Levi M. Hannon, Seth W. Bassett, William L. Evans III, David T. Paul and Brianne Apolinar

\begin{abstract}
The accompanying 1:100,000 scale geologic map (Open-File Map Series 106, Plate 1) depicts the areal distribution of bedrock and surficial geologic units for the U.S. Geological Survey (USGS) Saint Augustine 30 × 60 minute quadrangle. The map was constructed using a combination of field mapping (at 1:24,000 scale), compilation of data from existing maps (various scales), core and cuttings analyses and descriptions, geophysical log analyses and analyses of various Geographic Information System (GIS) data sources. The resulting data were compiled in ESRI $^{\circledR}$ ArcGIS $^{\circledR}$ ArcMap $^{\mathrm{TM}} 10.2$ software for publication as part of the Florida Geological Survey Open-File Map Series. Mapped units range from Middle Miocene to Quaternary. Important resources in the mapped area include potable groundwater, springs, sand, clay and coquina. Numerous springs, sinkholes and other karst features are present in the study area. The geologic maps produced for this area not only provide a greater understanding of the interaction between the geologic units, associated karst, springs and ecosystems, but have utility as a land management tool for economic development, mineral and energy production, and environmental protection for Florida. Examples include designing new construction projects, siting new water supply wells, energy production facilities, waste management and storage facilities, locating sources of mineable resources for aggregate supply, and protection of springs, surface and groundwater quality.
\end{abstract}

Keywords: Florida, geologic map, Avon Park Formation, Ocala Limestone, Hawthorn Group, Penney Farms Formation, Marks Head Formation, Coosawhatchie Formation, Cypresshead Formation, Anastasia Formation, geomorphology, hydrogeology, springs, karst, sinkholes, Floridan aquifer system, Clay County, Flagler County, Marion County, Putnam County, St. Johns County, Saint Augustine.

\section{INTRODUCTION}

Florida Geological Survey (FGS) Open-File Report (OFR) 102 accompanies Open-File Map Series (OFMS) 106, which is comprised of three plates. Plate 1 depicts the near-surface geology of the USGS Saint Augustine 30 x 60 minute quadrangle on a digital elevation model (DEM). Plate 2 depicts five geologic cross-sections, a stratigraphic correlation chart, and representative photos for several of the lithologic units in the study area. Plate 3 is a geomorphology map along with a DEM, showing locations of known springs and sinkholes, along with photographs of selected exposures within the study area.

The study area is located along the Atlantic coastline of Florida (Figure 1). It includes the communities of Saint Augustine, Palatka, Green Cove Springs, Crescent Beach and Beverley Beach. The quadrangle, which includes portions of Clay, Flagler, Marion, Putnam and St. Johns 
Counties, is bounded to the west by the USGS Gainesville 30 x 60 minute quadrangle, previously mapped under the STATEMAP program (Green et al., 2005), to the south by the USGS Daytona Beach 30 x 60 minute quadrangle, previously mapped under the STATEMAP program (Green et al., 2013a, 2013b) and to the north by the USGS Jacksonville 30 x 60 minute quadrangle (Figure 1). The St. Johns, Matanzas and Ocklawaha Rivers, along with numerous creeks and springs, occur in the map area. Recharge to and discharge from the Floridan aquifer system (FAS) occurs throughout the study area. The FAS is the primary source of water for springs and drinking water in the region.
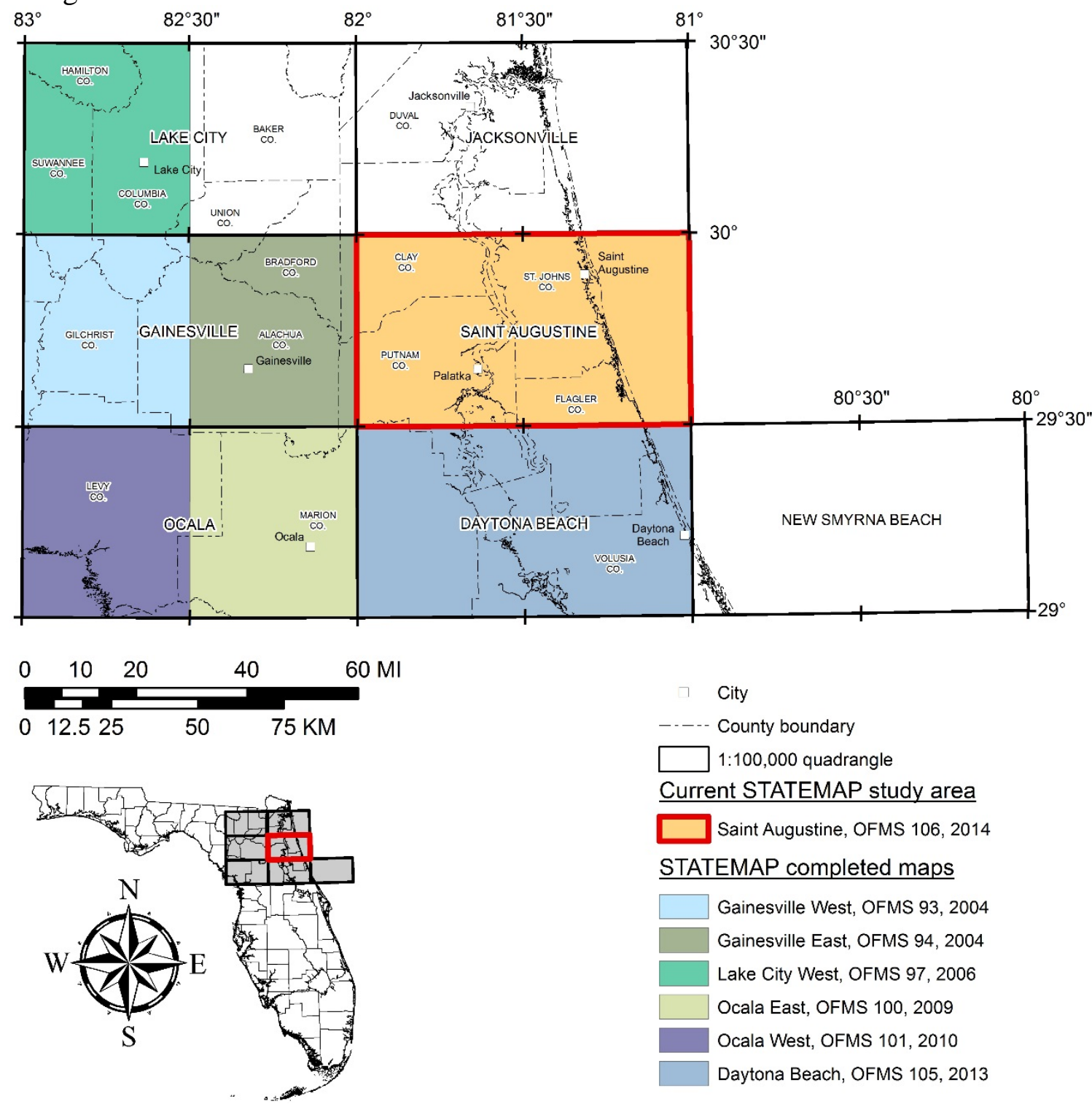

Current STATEMAP study area

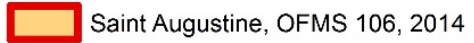

STATEMAP completed maps

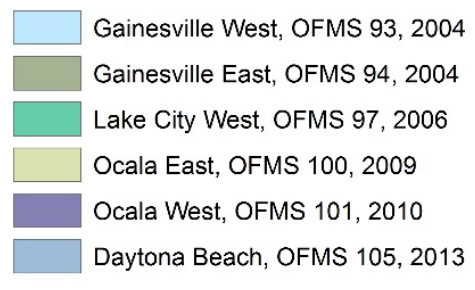

Figure 1. Nearby areas mapped under the FGS STATEMAP Program.

One objective for this report is to provide basic geologic information for the accompanying OFMS 106. Information provided by this report and the plates in OFMS 106 is intended for a diverse audience of professionals in geology, hydrology, engineering, environmental and urban planning, and laypersons, all of whom have varying levels of geologic knowledge. The maps can help users identify and interpret geologic features which impact activities related to groundwater 
quality and quantity, as well as aid in locating mineral resources, land-use planning and construction project design. Applied uses of the maps and data in this report include: 1) identifying potential new mineral resources, 2) characterizing zones of potential aquifer recharge and confinement, 3) aiding water-management decisions on groundwater flow and usage, 4) providing information on aquifer vulnerability to potential pollution, 5) ecosystem, wetlands and environmental characterization, and 6) recreation.

\section{Methods}

Mapping efforts consisted of: 1) compiling and reviewing existing geologic literature and data, 2) mapping geologic units in the field at 1:24,000 scale using standard techniques, 3) analyses of existing core and cuttings samples from the FGS sample repository, 4) new core drilling and analyses, 5) collecting and describing outcrop samples, and 6) preparing a geologic map, geological cross-sections and geomorphic map of the area. Fieldwork, performed during the fall of 2013 through the summer of 2014, consisted of sampling and describing numerous outcrops, river and borrow pit exposures and drilling of new cores.

Twenty new samples of geologic material were added to the FGS surface-sample archives (M-Series) and six cores (1079 feet or 238.9 meters total) were drilled for the project. Approximately 60 outcrops and exposures were also examined during the project. In addition to new cores collected for this study, approximately 250 sets of cores and cuttings archived in the Florida Geological Survey sample repository were examined and formation picks were made for mapped geologic units. In addition to the data from the cores and cuttings, several hundred formation picks derived from geophysical logs (see discussion beginning on page 22 for geophysical log interpretation) were utilized in developing various modeled surfaces. Figure 2 shows the locations of FGS cores, cuttings and St. Johns River Water Management District (SJRWMD) data points within the study area. Appendix A includes FGS wells with core and/or cuttings samples which were examined by the authors and/or used for the top of rock model or for determining the geologic surface and subsurface formations. An interpolated top of rock surface was developed using kriging along with a Digital Elevation Model (DEM) to generate an overburden thickness model. The map and accompanying plates were developed in ESRI ${ }^{\circledR}$ ArcGIS $^{\circledR}$ ArcMap $^{\mathrm{TM}} 10.2$ software for publication as part of OFMS 106.

Due to a lack of complete LiDAR coverage in the study area, a custom elevation model was created for this product. Two products were used to create this elevation model: a standard LiDAR elevation model with horizontal resolutions of five feet (1.5 meters), and a much coarser elevation model based off of topographic contours with a horizontal resolution of 100 feet (30.5 meters). LiDAR coverage existed for the entirety of St. Johns County, along with the Atlantic coastal shoreline and the St. Johns River valley. Portions of the remaining counties in the study area also had LiDAR available. The majority of both Clay and Putnam Counties lacked LiDAR coverage.

The hybrid elevation model was created by first combining all of the existing LiDAR and DEMs into a single raster. The 100 foot (30.5 meter) resolution (contour-based) DEM was resampled and aligned to match the resolution of the five foot (1.5 meter) LiDAR elevation models. A conditional statement was then used in ESRI ${ }^{\circledR}$ ArcGIS $^{\circledR} \operatorname{ArcMap}^{\mathrm{TM}} 10.2$ (ArcGIS) to create a new hybrid raster by selecting an elevation value from the LiDAR coverage if available; where LiDAR was not available, elevation values were drawn from the coarser, contour-based DEM. The elevation model that was generated by this process created "seams" along the join between the two different elevation models where parallel cells have large differences in their values. Attempts 
were made to fix the discrepancies by using smoothing techniques to average the cell values along the artifact boundary. Even with various smoothing algorithms applied to the merged dataset, it was not possible to achieve a perfectly smooth transition between the different types of elevation models. Examination of the resultant DEM will reveal one example of this along the border of northern Flagler County and southern St. Johns County (OFMS 106; Plate 3, Figure 2).

As a preliminary step for modeling, points from each of the datasets (cores, cuttings and geophysical logs) were used to generate a Triangular Irregular Network (TIN) of the surface. This TIN was then used as a method of examining and discarding any points that appeared anomalous compared to their surrounding values. During this step, any point which differed substantially from the surrounding points were indicated by a sharp depression or peak in the TIN surface; points found that differed by 75 or more feet from surrounding points were then removed from the dataset.

After this step was completed, an ordinary kriging method was used to generate a top of rock surface using the "stable" algorithm. Lag size was empirically calculated based on the total spatial extent of the combined datasets, and then adjusted slightly to improve model performance. The error values for all data were examined after each iteration of the model, and any points with a standardized error greater than five, or less than negative five, were discarded in order to improve the final model performance.

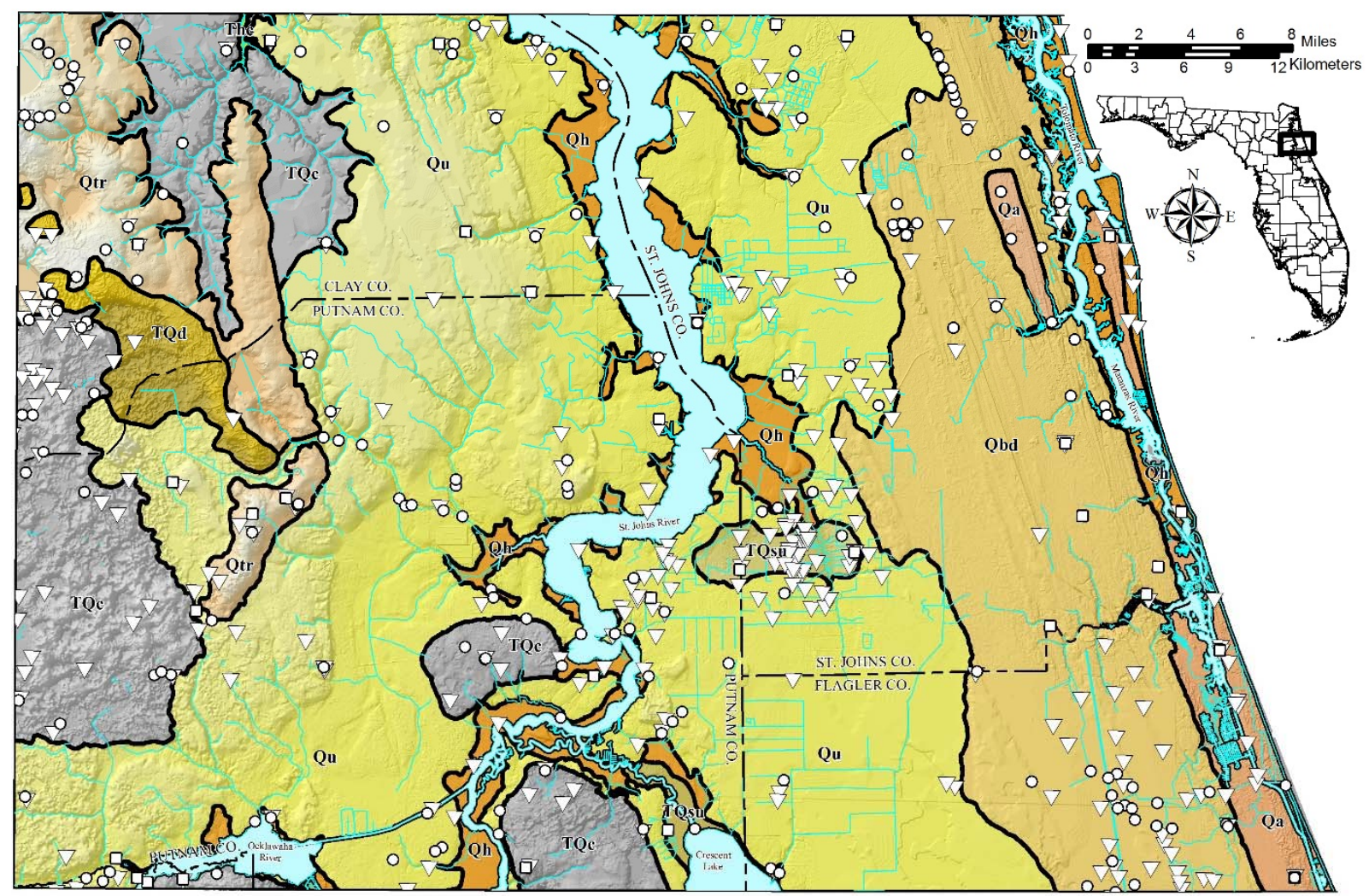

Figure 2. FGS cores (squares), cuttings (circles) and St. Johns River Water Management District geophysical logs (triangles) utilized for top of rock models. See discussion starting on page 14 for lithostratigraphic unit abbreviations and descriptions.

Much of the study area is blanketed by a veneer of undifferentiated Tertiary and Quaternary sediments and soils. For this reason, and in keeping with geologic mapping practices developed by Scott et al. (2001), the authors have adopted the policy of mapping the first named geologic 
unit within 20 feet (6.1 meters) of the surface. If Tertiary/Quaternary dune (TQd), undifferentiated Quaternary $(\mathrm{Qu})$, Holocene $(\mathrm{Qh})$ or Quaternary beach ridge and dune (Qbd) sediments attain a thickness greater than 20 feet (6.1 meters), then they appear as the mapped unit. If these undifferentiated sediments are less than 20 feet (6.1 meters) thick, then the underlying lithostratigraphic unit appears on the map. It is noted that the geologic map (OFMS 106, Plate 1) and geologic cross sections (OFMS 106, Plate 2) may appear to disagree slightly when depicting the upper unit due to this convention. This is due to the fact that geologic cross-section contacts are based on straight-line projection between wells and thus may lead to apparent thicknesses of units between wells that are not supported by field evidence or other wells nearby.

Parts of the region are heavily vegetated, and public access in several large sections of the mapped area was hindered by the presence of numerous wetlands, farms, ranches and privately owned land. Additionally, much of the coastal area is heavily developed with sub-divisions, many of which are gated communities. In instances where access was limited by these factors, the authors had to rely on existing well and core data. Fieldwork access was typically limited to public roads, Federal, State and County-owned lands.

\section{Previous Work}

The current study builds on many previous geologic investigations in and around the present map area which were useful in preparing this report. Preliminary county geologic maps for Clay, (Scott, 1992a) Flagler (Scott, 1992b), Marion (Scott, 1992c), Putnam (Scott, 1992d), and St. Johns (Scott, 1992e) Counties at 1:126,720 scale were previously published by the FGS. However, each of these geologic maps were constructed in an average time-frame of two weeks utilizing selected in-house geologic data with approximately one week of field work per county. Although these maps provided a starting point for the detailed geologic mapping undertaken for this project, significant refinement of prior geologic maps was possible as a result of this project. A statewide geologic map (Scott et al., 2001) also provided a framework for the current, more detailed mapping.

Scott (1988) published detailed descriptions, structure contour maps, and isopach maps for units of the Hawthorn Group. Huddlestun (1988) defined and discussed the Cypresshead Formation. This study also benefited greatly from the work performed during geologic mapping of the eastern portion of the USGS Gainesville $30 \times 60$ minute quadrangle (Green et al., 2005) and mapping of the USGS Daytona Beach 30 x 60 minute quadrangle (Green et al., 2013a; Green et al., 2013b). Williams et al., (2014, in review) mapped detailed geomorphology and geology for five quadrangles along the eastern edge of the study area as part of work on four National Park Service units in northeastern Florida. Some of the field relationships and stratigraphic problems were worked out during these projects and data gathered during work on them proved invaluable to the completion of this project.

\section{GEOLOGIC SUMMARY}

The near surface geology of the USGS 30 x 60 minute Saint Augustine quadrangle is composed of a complex mixture of Middle Eocene to Quaternary carbonate and siliciclastic sediments. A combination of factors, including fluvio-deltaic deposition, marine deposition, dissolution of underlying carbonates (karstification), erosion of sediments as a result of eustatic changes in sea level and structural features have influenced the geology of the study area. 
The oldest unit to crop out in the Saint Augustine quadrangle is the Tertiary/Quaternary Cypresshead Formation (TQc). Core and cuttings data indicate that the Tertiary Coosawhatchie Formation of the Hawthorn Group (Thc) is within 20 feet (6.1 meters) of the surface in the vicinity of South Fork Black Creek east of Trail Ridge (see OFMS 106, Plate 1). Although field exposures were not seen, our mapping convention and models led us to depict the unit on the geologic map.

Detailed description of the lithology of all units found in the study area begins on page 14 of this publication. Along with lithologic descriptions, several diagnostic foraminifera and echinoids aid in distinguishing Ocala Limestone from the underlying Avon Park Formation. The Avon Park Formation contains Cushmania [Dictyoconus] americana and Discorinopsis gunteri which are not found in the Ocala Limestone. The occurrence of Nummulites spp. and Lepidocyclina spp. in the Ocala Limestone helps to distinguish it from the Avon Park Formation in the mapped area.

Much of the Saint Augustine quadrangle is located within the Ocklawaha, Upper East Coast, and Lower St. Johns River Basins (Figure 3). There are numerous springs and spring-fed rivers within the study area, including five springs in Clay County, seven springs in Marion County, six springs in Putnam County and two in St. Johns County.

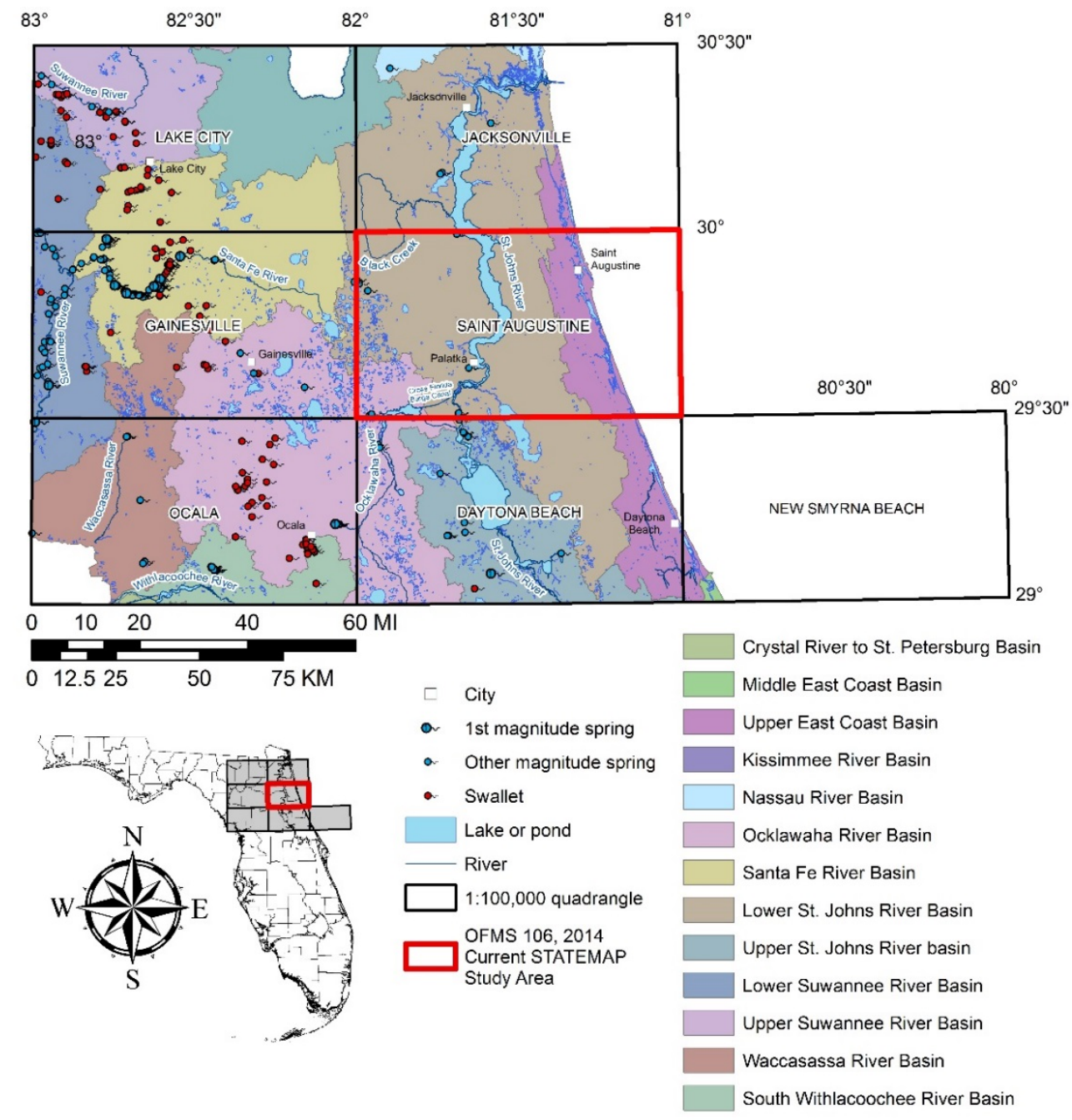

Figure 3. Location of selected river basins, springs and other water bodies. 
Portions of the recharge areas for many of the aforementioned springs are located within the study area. Many of these springs have shown significant increases in pollutants in the last few decades, particularly nitrate (Phelps, 1994, 2004; Jones et al., 1996; Scott et al., 2002; Upchurch et al., 2004; Copeland et al., 2009). Detailed geologic mapping of lithostratigraphic units in this area provides critical data needed for future assessments of the vulnerability of the aquifer systems and springs to contamination. Understanding the surficial geology of the map area is a key factor in developing management and protection plans, not only for the springs, but for the Floridan aquifer system.

Karst processes have extensively modified the topography of the region, and continue to actively shape it today. Karst topography is characterized by solutional features, subterranean drainage, and caves (Poucher and Copeland, 2006). Downward infiltration of slightly acidic rain and surface water through preferential pathways, such as joints, fractures, and bedding planes, combined with groundwater fluctuations, cause dissolution of the carbonate rocks (Waltham et al., 2005).

The variability of the karst observed within the study area is closely related to the thickness of overburden and the presence/absence of Cypresshead Formation and Hawthorn Group clays within the overburden mantling the region's carbonate rocks. These clays are often the sediments which create a bridge over any cavities which have formed within the carbonates. The study area can be divided into two main karst regions: the Central Lakes District and the Barrier Island Sequence District (see OFMS 106, Plate 3). Generally, the overburden sediments are thickest and contain a higher percentage of clay and clayey sediments, resulting more frequently in the occurrence of cover-collapse sinkholes, to the west and south of Trail Ridge. To the east of Trail Ridge, extending towards the St. Johns River valley, the overburden sediments are generally thinner (see OFMS 106, Plates 2 and 3) resulting in both cover-subsidence and cover-collapse sinkholes (Sinclair and Stewart, 1985).

\section{Structure}

Several structural features have affected the geology of the region (Figure 4). The Peninsular Arch, a structurally high area which affected deposition from the Cretaceous to the early Cenozoic, is the dominant subsurface feature of the Florida peninsula (Applin and Applin, 1944; Applin, 1951; Puri and Vernon, 1964; Williams et al., 1977; Schmidt, 1984; Miller, 1986; Scott, 1997). The axis of the Peninsular Arch, which lies just west of the study area, extends from southeastern Georgia to the vicinity of Lake Okeechobee in southern Florida in a general northwest to southeast trend. The crest of the arch passes beneath Alachua County and is highest in Union and Baker Counties northwest of the study area. The arch was a topographic high during most of the Cretaceous Period and had Upper Cretaceous sediments deposited upon it (Applin, 1951). It formed a relatively stable base for Eocene carbonate deposition (Williams et al., 1977). The arch did not affect mid-Tertiary to Holocene sediment deposition (Williams et al., 1977; Scott, 1997).

The Sanford High, named by Vernon (1951a), is a positive feature located in Volusia and Seminole Counties just south of the study area. It is a prominent structure affecting the near surface depositional and post-depositional environments within the map area (Figure 4). Vernon (1951a) described this feature as "a closed fold that has been faulted, the Sanford high being located on the upthrown side”. The Ocala Limestone and Hawthorn Group are missing over this feature and postHawthorn Group sediments (undifferentiated Pliocene/Pleistocene shelly sediments) directly overlie the Avon Park Formation in the vicinity of the Sanford High (Green et al, 2013a). 
The St. Johns Platform, introduced by Riggs (1979a, 1979b), extends northward from the Sanford High into St. Johns County. This platform, which is expressed on the erosional surface of the Ocala Limestone, dips gently north-northwest towards Jacksonville (Scott, 1983). This is evident throughout the map area (OFMS 106; Plate 2). Undifferentiated sediments, thickest on Trail Ridge and its flanks, have been deposited on the Miocene Hawthorn Group (Th), Tertiary/Quaternary Cypresshead Formation (TQc) and undifferentiated Pliocene/Pleistocene shelly sediments (TQsu). These consist of residual clays, shells, quartz sands, and aeolian sands deposited during the Miocene to Holocene (Scott, 1997).

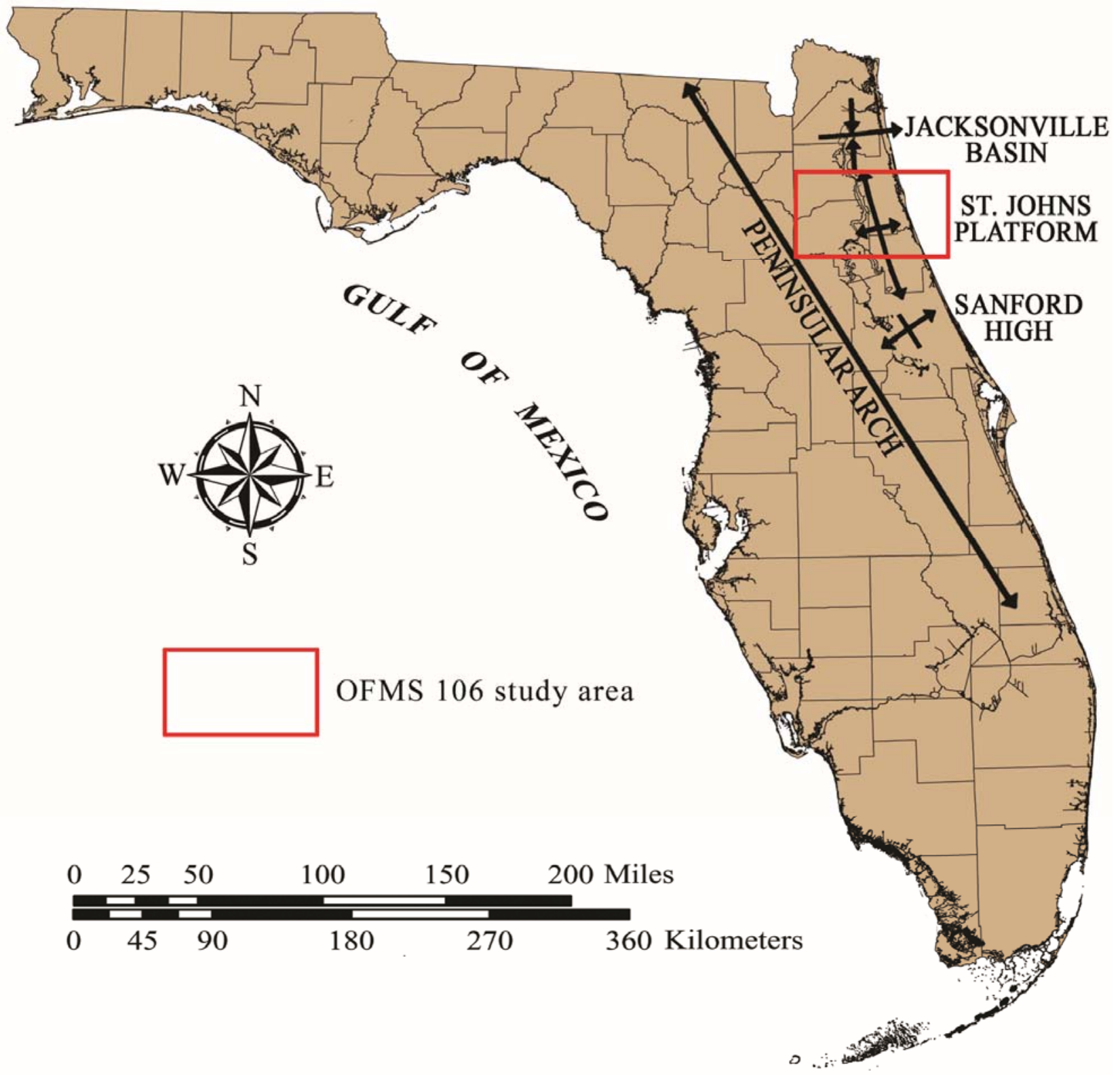

Figure 4. Principal subsurface structures of north Florida (modified from Scott, 1988). 


\section{Geomorphology}

Healy (1975) recognized eight possible marine terraces within the study area (Figure 5) based upon elevations above mean sea level (MSL): the Silver Bluff terrace at elevations between 1 and 10 feet ( 0.3 and 3 meters), the Pamlico terrace at elevations between 10 and 25 feet ( 3 and 7.6 meters), the Talbot terrace at elevations between 25 and 42 feet (7.6 and 12.8 meters), the Penholoway terrace at elevations between 42 and 70 feet (12.8 and 21.3 meters), the Wicomico terrace at elevations between 70 to 100 feet (21.3 to 30.5 meters), the Sunderland/Okefenokee terrace at elevations between 100 and 170 feet (30.5 and 51.8 meters) and the Coharie terrace at elevations between 170 and 215 feet (51.8 and 65.5 meters). He combined the Hazlehurst (Cooke 1939), Coastwise delta plain (Vernon, 1951b), and part of the high Pliocene terrace of MacNeil (1950) which range in elevation from 215 to 320 feet (65.5 and 97.5 meters). Detailed discussions and correlations of these marine terraces and relict shorelines have been attempted by many authors, including Matson and Sanford (1913), Cooke (1931, 1939), Flint (1940, 1971), MacNeil (1950), Alt and Brooks (1965), Pirkle et al. (1970), Healy (1975), and Colquhoun et al. (1991).
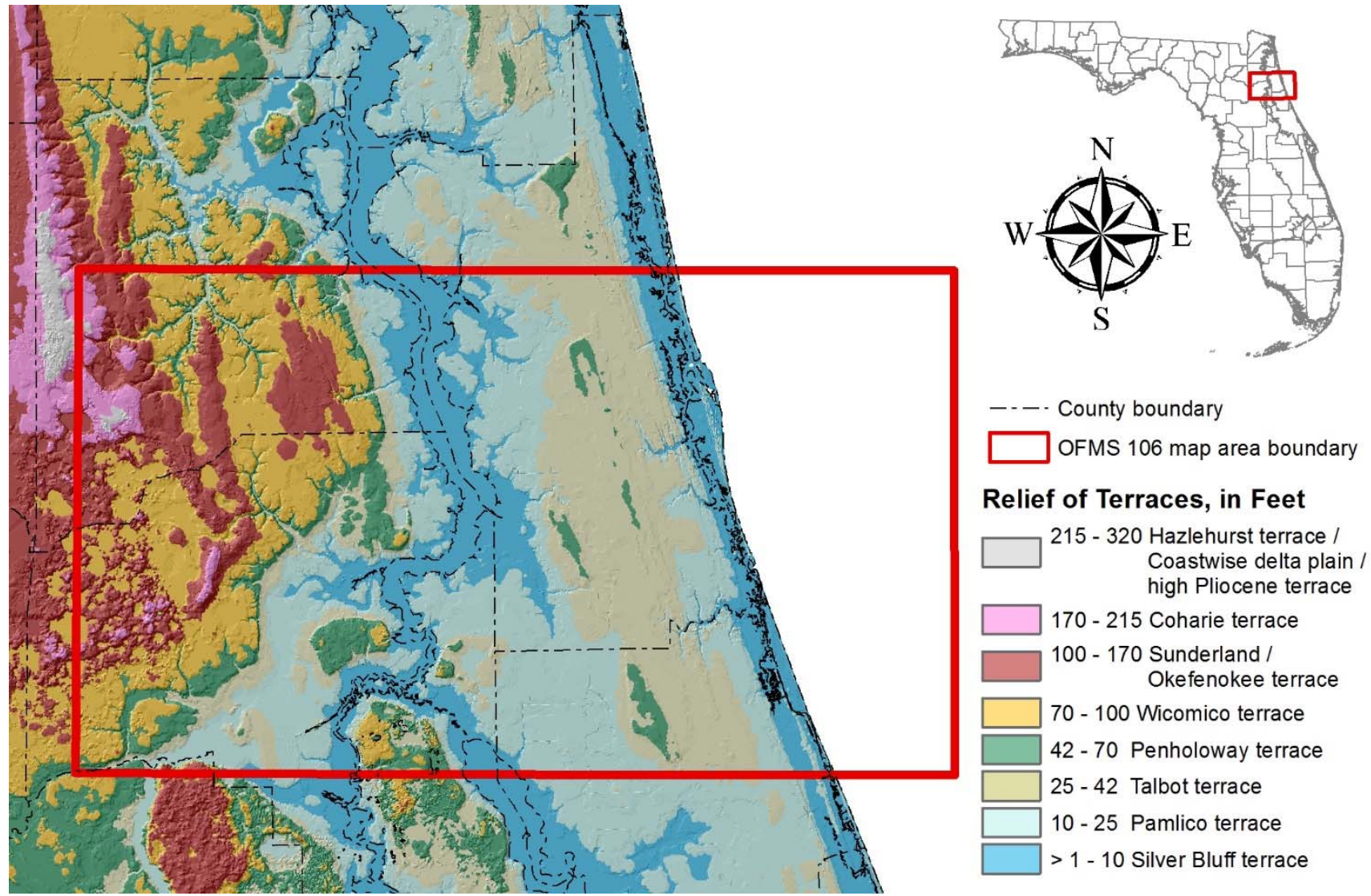

Figure 5. Terraces in the study area (after Healy, 1975).

According to Scott et al., (in preparation), the study area falls within two geomorphic districts: the Barrier Island Sequence District and the Central Lakes District (OFMS 106; Plate 3, Figure 3). These districts are further subdivided into terranes (OFMS 106; Plate 3, Figure 4) by Scott et al., (in preparation). 


\section{FLORIDA GEOLOGICAL SURVEY}

\section{Barrier Island Sequence District}

The Barrier Island Sequence District extends into Florida from Georgia. The district is characterized by beach ridges, dunes and paleo-lagoons. The district extends from the GeorgiaFlorida state line southward to the vicinity of Lake Okeechobee. It lies to the east of the Central Lakes District and north of the Everglades District (OFMS 106; Plate 3, Figure 3). Within the mapped area, the District is divided into three terranes (OFMS 106; Plate 3, Figure 4): the Atlantic Coastal Complex, the Duval Upland and the Lower St. Johns River Valley. Elevations within the District range from sea level to more than 145 feet (44.2 meters) above MSL. The surficial and shallow subsurface sediments of the district, presumably deposited during the Pliocene to Holocene, lie unconformably on sediments ranging from the Middle Eocene Avon Park Formation to the Oligocene-Miocene Hawthorn Group.

Beach ridge plains occur in several areas of the Barrier Island Sequence District at elevations ranging from near sea level to more than 75 feet (23 meters) above MSL. In the study area, these mostly occur in the Atlantic Coastal Complex (OFMS 106; Plate 3, Figure 1). Drainage patterns in these areas may be strongly controlled by the relict beach ridges, forming a distinct trellis pattern. The beach ridge swales are often swampy and control the development of lakes.

The Barrier Island Sequence District also contains relict (or paleo) lagoons. The occurrence of the lagoonal features is most prominent in the southern portion of the district near the headwaters of the St. Johns River. White (1970) thought that this area was not a paleo-lagoon but a beach ridge plain that had been reduced in stature by dissolution of incorporated shell material. He stated that there were relict beach ridges in the area and that the ridges controlled the drainage. Modern topographic maps, however, do not show the beach ridges nor do they reveal a drainage pattern indicative of beach ridges.

This paleo-lagoon lies between the Atlantic Coastal Ridge on the east and a prominent erosional scarp on the west. The scarp toe occurs at approximately 30 feet (9.1 meters) above MSL and extends nearly continuously from the southernmost portion of the Barrier Island Sequence District northward to the Florida-Georgia state line. The paleo-lagoon extends uninterrupted from the southern end of the district to southern Volusia County. Northward from southern Volusia County the relict lagoon is either interrupted or partially covered by beach ridges. However, the lagoon can be recognized as far north as the vicinity of Jacksonville in Duval County.

\section{Atlantic Coastal Complex}

The Atlantic Coastal Complex extends from the St. Johns River in Duval County to northern Brevard County (OFMS 106; Plate 3, Figure 4). In the study area, this terrane consists of Pleistocene through recent barrier beach ridges and dunes that are consistent with the terrane as a whole. Elevations range from sea level to 90 feet (27.4 meters) above MSL. There are multiple coast parallel creeks and swamps in the swales separated by ridges and broad scale development of trellis drainage. Some of the major water features include the Matanzas, Tolomato and Guana rivers, and Pellicer, Moses and Moultrie creeks. The Intracoastal Waterway, particularly in the southeastern part of the study area, separates the modern barrier island from the mainland to the west. The terrane has varying thickness of undifferentiated Quaternary sediments, undifferentiated Tertiary and Quaternary shelly sediments and outcrops of the Pleistocene Anastasia Formation near the Atlantic coast (OFMS 106, plate 2). 


\section{Duval Upland}

The Duval Upland is a broad feature extending from Putnam County in the south to Nassau County and the Georgia boundary with Florida along the St. Marys River in the north (OFMS 106; Plate 3, Figure 4). It is an area of higher elevation to the west of the Lower St. Johns River Valley and the St. Marys Plain (OFMS 106; Plate 3, Figure 3). It is underlain by sediments of the Cypresshead Formation along the western edge and undifferentiated Quaternary sands along the eastern edge. Notably, across the Duval Upland, mixed dendritic and trellis drainage reveal that, at least in part, this terrane was originally deposited having some aspect of ridge and swale topography akin to the Atlantic Coastal Complex. This affinity is why the Duval Upland terrane is included within the Barrier Island Sequence District. Statewide, and within the mapped area, elevations range from sea level to approximately 145 feet (44.2 meters) above MSL.

\section{Lower St. Johns River Valley}

The Lower St. Johns River Valley has been hypothesized by Scott (2013, personal communication) as part of a paleo-lagoon. The relict lagoon feature extends nearly continuously from the headwaters of the St. Johns River in Palm Beach County to central Duval County. In Volusia County, the paleo-lagoon is either partially interrupted or partially covered by beach ridges. The southern end of this interruption corresponds to the westward turn of the St. Johns River as it occupies the St. Johns River Offset (OFMS 106; Plate 3, Figure 4). The southern end of the Lower St. Johns River Valley includes Crescent Lake and extends northward to central Duval County where the St. Johns River turns east toward the Atlantic Ocean and some beach ridge uplands separate the St. Johns River Valley from the drainages associated with the Nassau and St. Marys rivers. Elevations within the terrane range from sea level to more than 95 feet (29.0 meters) above MSL. Within the study area, elevations range from sea level to 90 feet (27.4 meters) above MSL. Variable thicknesses of undifferentiated Quaternary sediments lie on undifferentiated Tertiary/Quaternary shelly sediments or the Hawthorn Group in the terrane.

\section{Central Lakes District}

The Central Lakes District occupies most of the Central Highlands of Cooke (1939) in peninsular Florida. The district extends from eastern Alachua County, southeastern Bradford County and southern Clay County to southernmost Highlands County (OFMS 106; Plate 3, Figure 3). A thick (up to 200 feet [61 meters]) sequence of siliciclastic and carbonate sediments of the Hawthorn Group and siliciclastic sediments of the Cypresshead Formation and undifferentiated sediments overlie the Ocala Limestone in the district. Dissolution of the limestone and subsequent subsidence or collapse has created the characteristic rolling hills, sinkhole lakes and dry sinks that dominate the landscape. Much of the district is internally drained due to the karst features and the permeable sand cover. District-wide elevations range from near sea level to over 300 feet $(91.4$ meters) above MSL. Within the mapped area, elevations vary from near sea level along portions of the St. Johns River to 285 feet (86.9 meters) above MSL on Trail Ridge. In the study area, the Central Lakes District includes the Crescent City Ridge, the Fort McCoy Plain, the Hawthorne Lakes Region, the Mt. Dora Ridge, the Ocklawaha River Valley, Palatka Hill, the St. Johns River Offset, and Trail Ridge (OFMS 106; Plate 3, Figure 4). Many of these features were once part of 


\section{FLORIDA GEOLOGICAL SURVEY}

a more extensive Cypresshead Formation upland that subsequently was erosionally altered leaving remnant highs.

\section{Crescent City Ridge}

The Crescent City Ridge lies in northwestern Volusia County and southeastern Putnam County (OFMS 106; Plate 3, Figure 4). It is located between the St. Johns River Offset and the Lower St. Johns River Valley. Crescent Lake, which likely represents a portion of the paleopathway of the ancestral St. Johns River abandoned when the river began to occupy the St. Johns River Offset, lies at the eastern toe of the ridge. Elevations vary from approximately MSL to 125 feet (38.1 meters) above MSL. Relief on the ridge can be substantial due to karst influences. The terrain is a rolling, karstic landscape with closed-basin lakes. A thin sequence of undifferentiated Quaternary sediments overlies the Cypresshead Formation and undifferentiated Tertiary/Quaternary shelly sediments.

\section{Fort McCoy Plain}

The Fort McCoy Plain is a relatively flat, poorly to moderately drained area just east of the Ocala Karst Hills and southeast of the Hawthorne Lakes Region in the southwest corner of the study area (OFMS 106; Plate 3, Figure 4). Scattered sinkholes are present within the terrane and elevations range from approximately 15 feet (4.6 meters) to approximately 90 feet (27.4 meters) above MSL within the study area. The Fort McCoy Plain is underlain by sediments of the Hawthorn Group, which are mantled with variable thicknesses of undifferentiated Quaternary sediments (Scott et al., 2001; Green et al., 2009a, 2009b).

\section{Hawthorne Lakes Region}

The Hawthorne Lakes Region is bounded to the north and east by Trail Ridge, to the east by the Duval Upland, to the south by the Fort McCoy Plain and the Ocklawaha River Valley and to the northwest by the Southern Okeefenokee Basin (OFMS 106; Plate 3, Figure 4). The lakes in the Hawthorne Lakes Region formed through karst processes and were modified by subsequent surficial erosion. Surficial erosion has caused some of the formerly closed basins to coalesce and develop outflow streams. Elevations in the terrane range from approximately 10 feet (3.1 meters) above MSL for the water level in the lakes to approximately 225 feet (68.6 meters) above MSL on the hills. Relief generally decreases to the south, as does the elevation range. The Hawthorne Lakes Region is underlain by sediments of the Cypresshead Formation and undifferentiated Quaternary sediments.

\section{Mt. Dora Ridge}

The Mt. Dora Ridge occurs from western Orange County to Marion and Putnam Counties, where it terminates near the southwestern corner of the study area (OFMS 106; Plate 3, Figures 1 and 4). It is bound to the west by the Ocklawaha River Valley, Tavares Lakes Region, Lake Wales Ridge Complex, to the south and east by the Osceola Plain, and to the east by the Orlando Ridge, Wekiva Plain, Lake Plain and St. Johns River Offset Valley. The terrain is a rolling karstic landscape with numerous lakes. Elevations on the Mt. Dora Ridge range from 5 feet (1.5 meters) 
to 195 feet (59.4 meters) above MSL statewide and from 5 feet (1.5 meters) to 170 feet (51.8 meters) above MSL within the study area. Relief often exceeds 100 feet (30.5 meters). Karst processes acting through a thick sequence of siliciclastic sediments (deep-cover karst) created the landscape. Dissolution of the Ocala Limestone and carbonates within the Hawthorn Group is responsible for the development of the Mt. Dora Ridge's distinctive landscape. Tertiary/Quaternary dune sediments overlie the Cypresshead Formation on part of the Mt. Dora Ridge. Elsewhere, the Cypresshead Formation lies on the Hawthorn Group.

\section{Ocklawaha River Valley}

The Ocklawaha River Valley extends from near the Lake-Marion County line northward to the Marion-Putnam County line (OFMS 106; Plate 3, Figure 4). In the study area, the valley abuts the St. Johns River Offset, Mt. Dora Ridge, Fort McCoy Plain, the Hawthorne Lakes Region and the Duval Upland where the river becomes confined to a narrow corridor (OFMS 106; Plate 3, Figures 1 and 4). The headwaters of the Ocklawaha River occur in Lake Griffin in the Tavares Lakes Region, a broader and more karstic portion of the Central Lakes District. The terrane is underlain by the Ocala Limestone, Hawthorn Group, Cypresshead Formation and undifferentiated Quaternary sediments. Elevations of the valley range from sea level to 105 feet (32.0 meters) above MSL statewide and sea level to 70 feet (21.3 meters) above MSL within the study area.

\section{Palatka Hill}

Palatka Hill, in Putnam County, appears as a remnant hill stranded in the broader feature of the St. Johns River valley. Where the St. Johns River Offset turns toward the east-northeast, the river has followed its current course south of Palatka Hill, but there is also an extensive eroded plain to the west and north of Palatka Hill. This remnant feature is at the junction of the St. Johns River Offset and the Lower St. Johns River Valley where the St. Johns River turns to the northnorthwest, continuing the coastal sub-parallel trend in line with the Upper St. Johns River Valley further south. The Palatka Hill terrane appears to share affinity to both the Crescent City Ridge to the southeast and the Duval Upland to the north and northwest (OFMS 106; Plate 3, Figures 1 and 4). It exhibits overland drainage incision like the Duval Upland, as may be observed at Ravine Gardens State Park, but is not devoid of isolated karst lakes as are found in the Crescent City Ridge. Palatka Hill elevations range from 5 feet (15 meters) to 100 feet (30.5 meters) above MSL. The terrane consists of undifferentiated Quaternary sediments on Cypresshead Formation.

\section{St. Johns River Offset}

The St. Johns River flows northward from the headwaters in Palm Beach County, flowing into the Atlantic Ocean in Duval County (OFMS 106; Plate 3, Figure 4). The upper and lower St. Johns River valleys follow pathways that are closer to the Atlantic coastline than the middle reach of the river between Sanford and Palatka. At the approximate latitude of Sanford, Seminole County, the river jogs westward then northward in a narrow valley bounded in the study area by the Mt. Dora Ridge on the west and the Crescent City Ridge on the east. White (1970) named and described the St. Johns River Offset. Elevations in the terrane vary from sea level to 75 feet (22.9 meters) above MSL statewide and sea level to 60 feet (18.3 meters) above MSL in the study area. White believed that this portion of the St. Johns River's pathway was first developed in the 
Pliocene or early Pleistocene by dissolution of the underlying Eocene carbonate sediments. Pirkle (1971) suggested that the dissolution along the west to east trend resulted from faulting and fracturing of the Eocene rocks. White (1970) believed that a complex geomorphic history was necessary to force the St. Johns River out of its coast parallel course and into a more inland, older valley. Within the Offset there are varying thicknesses of undifferentiated Quaternary sediments overlying the Ocala Limestone.

\section{Trail Ridge}

Trail Ridge is a 130 mile (209 kilometer) long sand ridge that extends southward from the Altamaha River in southern Georgia to northern Putnam County in the west-northwest portion of the study area (OFMS 106; Plate 3, Figure 4). It is bound to the west by the Southern Okeefenokee Basin, to the east by the Duval upland and to the south by the Hawthorne Lakes Region (OFMS 106; Plate 3, Figure 4). This feature as mapped includes the Baywood Promontory of Pirkle et al., (1970). Elevations of the terrane range from 50 feet (15.2 meters) above MSL to 305 feet (93.0 meters) above MSL statewide and 50 feet (15.2 meters) to 285 feet (86.9 meters) above MSL within the mapped area. Trail Ridge sands consist of unconsolidated to slightly indurated white to tan, medium to fine quartz beach ridge sands in some areas containing an average of 3 percent heavy minerals, of which approximately 45 percent are titanium-rich minerals, consisting of ilmenite, leucoxene, and rutile. The average $\mathrm{TiO}_{2}$ content of these minerals is approximately 69 percent. Other common heavy minerals include staurolite, zircon, kyanite, sillimanite, corundum, topaz, and tourmaline.

\section{LITHOSTRATIGRAPHIC UNITS}

\section{Tertiary System}

\section{Eocene Series}

\section{Avon Park Formation}

The Middle Eocene Avon Park Formation (Tap), first described by Applin and Applin (1944), is entirely a subsurface unit within the USGS Saint Augustine 30 x 60 minute quadrangle. It was encountered in many of the wells utilized for this study and efforts were made to include it in the geologic cross sections where suitable well coverage existed (see OFMS 106, Plate 2).

Lithology of the Avon Park Formation varies between limestone and dolostone. The limestones consist of cream to light brown to tan, poorly to well-indurated, variably fossiliferous grainstone and wackestone, with rare mudstone. The limestones are often interbedded with tan to brown, very poorly to well-indurated, very fine to medium crystalline, fossiliferous (molds and casts), vuggy dolostones. Minor clay beds and organic-rich laminations may occur, especially at or near the top of the unit. Accessory minerals include chert, pyrite, celestine, gypsum and quartz (some as doubly-terminated euhedral crystals "floating" in vugs).

Fossils present in the unit include molluscs, foraminifera (Spirolina sp., Lituonella floridana, Bolivina spp., Cushmania [Dictyoconus] americana), Cribrobulimina cushmani, and Fabiana cubensis, echinoids (Neolaganum [Peronella] dalli), algae and carbonized plant remains. Porosity in the Avon Park Formation is generally intergranular in the limestone section. Fracture 
porosity occurs in the more densely recrystallized dolostone and intercrystalline porosity is characteristic of sucrosic textures. Pinpoint vugs and fossil molds are present to a lesser extent.

Distinguishing between the Middle Eocene Avon Park Formation and the unconformably overlying unit, the Upper Eocene Ocala Limestone, can at times be difficult in the study area. Dolomitization of the Avon Park Formation and common recrystallization of the lowermost Ocala Limestone has significantly altered the original rock lithology and fabric. Fossil indicators are only somewhat helpful because the latest deposits of the Avon Park Formation and the earliest deposits of the Ocala Limestone are both bank assemblages, consistent with deposition in a shallow-water limestone bank or plateau, not unlike the present day Bahama Banks (Bryan, 2004).

The top of the Avon Park ranges from approximately 80 feet (24.4 meters) below MSL in W-17173 (OFMS 106; Plate 2, cross-section D-D') to approximately 500 feet (152.4 meters) below MSL in W-3478 (OFMS 106; Plate 2, cross-sections A-A'). Due to limited coverage of deeper wells, the total thickness of the Avon Park Formation was not investigated in this study. The Avon Park Formation forms part of the FAS (Southeastern Geological Society Ad Hoc Committee on Florida Hydrostratigraphic Unit Definition, 1986).

\section{Ocala Limestone}

The Upper Eocene Ocala Limestone (To), first described by Dall and Harris (1892), is a biogenic marine limestone comprised largely of foraminifera, molluscs, echinoids and bryozoans. The Ocala Limestone, which sits unconformably on the Avon Park Formation throughout the study area, is thin to absent in the vicinity of the Sanford High (Green et al., 2013a, 2013b).

Based on lithologic differences, the Ocala Limestone can be informally subdivided into an upper and lower unit (Scott, 1991). This subdivision, while often apparent in cores and quarries, is not readily apparent in cuttings. As a consequence of this, the geologic cross-sections do not break out the upper and lower Ocala Limestone. The upper unit is typically a white to cream, fineto coarse-grained, poorly to well-indurated, moderately to well-sorted, very fossiliferous limestone (wackestone, packstone, and grainstone). Fossils commonly include foraminifera, bryozoans, molluscs, and a rich diversity of echinoids. The lower unit is typically a white to cream, fine- to medium-grained, poorly to moderately indurated, moderately to well-sorted limestone (grainstone to packstone). Fossils include foraminifera (Lepidocyclina ocalana, Amphistegina pinarensis, Nummulites [Camerina] vanderstoki, Nummulites [Operculinoides] ocalana), bryozoans, algae, molluscs, echinoids, and crustaceans.

The Ocala Limestone occurs throughout the study area and is highest along the southwestern portion of the map area (OFMS 106, Plate 2). The top of the Ocala Limestone ranges from 27 feet (8.2 meters) below MSL in W-17173, (OFMS 106; Plate 2, cross-section D-D') to 340 feet (103.6 meters) below MSL in W-14476 (OFMS 106; Plate 2, cross-sections D-D' and AA'). Only a few wells utilized for geologic cross-sections penetrated the entire thickness of the Ocala Limestone. In these wells, the thickness of the Ocala Limestone ranges from 53 feet (16.2 meters) in W-17173 (OFMS 106; Plate 2, cross-section D-D') to 217.5 feet (82.4 meters) in W18580 (OFMS 106; Plate 2, cross-section B-B'). The Ocala Limestone is generally thickest in the eastern portion of the study area. The Ocala Limestone forms part of the FAS (Southeastern Geological Society Ad Hoc Committee on Florida Hydrostratigraphic Unit Definition, 1986). 


\title{
FLORIDA GEOLOGICAL SURVEY
}

\section{Miocene Series}

\author{
Hawthorn Group
}

Sediments of the Miocene Hawthorn Group are thought to have been deposited over the Peninsular Arch throughout the study area, but erosion and karstification have removed these sediments from the crest of the Ocala Platform (Cooke, 1945; Espenshade and Spencer, 1963; Scott, 1983). The unit is also missing in the vicinity of the Sanford High (Scott, 1988). Hawthorn Group sediments within the study area consist of phosphatic siliciclastics (sands, silts and clays) and carbonates (dolostone with minor limestone). Fossils in the Hawthorn Group are sparse but may include vertebrates, corals, and molluscs. Benthic foraminifera characteristic of the Hawthorn Group include Archaias spp. and Sorites sp. Williams et al. (1977) report that the most commonly found fossils are oysters and coral heads.

Within the mapped area, the Hawthorn Group is composed of (in ascending order) the Penney Farms Formation (Thpf), the Marks Head Formation (Thmh) and the Coosawhatchie Formation (Thc; OFMS 106, Plate 2, Figure 2). While these formations can be identified and delineated in cores, they often can be difficult to differentiate in cuttings, particularly where cavings cause mixing of the sediments during drilling. In these instances, they are referred to as undifferentiated Hawthorn Group (Th) on the cross-sections. This is most common in the southwestern portion of the map area (OFMS 106; Plate 2, cross-section C-C'). Unit descriptions for the Hawthorn Group listed below are summaries and the reader is referred to Scott (1988) for a more complete discussion of lithologies, variability and relationships of these lithologically complex formations. Hawthorn Group sediments are unconformably overlain by undifferentiated Tertiary/Quaternary shelly sediments (TQsu), Cypresshead Formation (TQc), Tertiary/Quaternary dunes (TQd), undifferentiated Quaternary sediments (Qu) and Trail Ridge sands (Qtr).

Hawthorn Group sediments occur throughout the mapped area (OFMS 106, Plate 2). The top of the Hawthorn Group ranges between 70 feet (21.3 meters) above MSL in W-15183 (OFMS 106; Plate 2, cross-section B-B') to 88 feet (26.8 meters) below MSL in W-13746 (OFMS 106; Plate 2, cross-section A-A'). The Hawthorn Group sediments range in thickness from 22 feet (6.7 meters) in well W-17173 (OFMS 106; Plate 2, cross-section D-D') to 290 feet (88.4 meters) in well W-14476 (OFMS 106; Plate 2, cross-section A-A'). Sediments of the Hawthorn Group form the Intermediate aquifer system/Intermediate confining unit (IAS/ICU; Southeastern Geological Society Ad Hoc Committee on Florida Hydrostratigraphic Unit Definition, 1986).

\section{Penney Farms Formation}

The Lower Miocene Penney Farms Formation (Thpf) consists of variable admixtures of dolostone, quartz sand, phosphatic sand and clay. The sand content is variable and at times the unit becomes a dolomitic sand. Phosphatic sand is common and may be present in amounts exceeding 25 percent with an average of 5 to 10 percent (Scott, 1988). Clay percentages are generally minor (less than five percent) and often increase towards the top of the unit in the dolostones. The dolostones are medium-gray to pale-yellowish brown and are generally moderately- to wellindurated. Mollusc molds are common in the dolostones. Bored hardgrounds, burrows and intraclasts are common in the hard, finer-grained dolostones in the lower portion of the unit. These intraclasts are composed of dolomite similar to the rest of the unit, but they often have rims of phosphate replacement along the edges of the clasts (OFMS 106; Plate 2, Figure 3). Limestone, which occurs sporadically in the lower portion of the unit, is generally dolomitic, phosphatic, and 
quartz sandy. The Penney Farms Formation unconformably overlies the Ocala Limestone within the mapped area. Where present in the mapped area, it is overlain unconformably by the Marks Head Formation (Hawthorn Group). The base of the Marks Head Formation is placed at the contact between the darker-colored sands and clays of the upper Penney Farms and the generally lighter-colored interbedded sands, clays, and dolostone of the Marks Head Formation. Sediments of the Penney Farms Formation occur throughout most of the mapped area (OFMS 106, Plate 2). The top of the Penney Farms Formation ranges from near sea level in W-14301 (OFMS 106; Plate 2, cross-section C-C') to 230 feet (70.1 meters) below MSL in W-14476 (OFMS 106; Plate 2, cross-sections A-A' and D-D'). The Penney Farms Formation ranges in thickness from nonexistent in W-15183 (OFMS 106; Plate 2, cross-section B-B') and W-17173 (OFMS 106; Plate 2, cross-section D-D') to 129 feet (39.3 meters) in well W-533 (OFMS 106; Plate 2, cross-sections A-A' and C-C').

\section{Marks Head Formation}

The Lower Miocene Marks Head Formation (Thmh) consists of interbedded sands, clays and dolostones. Limestone, while uncommon, does occur within the unit (Scott, 1988). Dolostones are generally quartz sandy, phosphatic and clayey. Colors of the dolostones range from yellowishgray to olive gray. Induration, which varies inversely with the clay content, ranges from poorly consolidated to well indurated. Phosphate content typically ranges up to five percent but may occasionally be significantly higher. Quartz sand content ranges from five percent to greater than 50 percent. The unit is overlain unconformably by the Coosawhatchie Formation, although this unconformity is often not readily apparent. In general, the contact between the Coosawhatchie and Marks Head formations is placed at the top of the first hard carbonate bed or light-colored clay unit below the darker-colored, clayey, dolomitic quartz sands and dolostones of the basal Coosawhatchie Formation (Scott, 1988). Sediments of the Marks Head Formation occur throughout most of the mapped area (OFMS 106, Plate 2). The top of the Marks Head Formation ranges from 10 feet (3.1 meters) above MSL in W-15183 (OFMS 106; Plate 2, cross-section B-B') to 195 feet (59.4 meters) below MSL in W-3478 (OFMS 106; Plate 2, cross-section A-A'). The Marks Head Formation ranges in thickness from non-existent in well W-17173 (OFMS 106; Plate 2, cross-section D-D') to 87 feet (26.5 meters) in well W-533 (OFMS 106; Plate 2, cross-sections A-A' and C-C').

\section{Coosawhatchie Formation}

The Middle Miocene Coosawhatchie Formation (Thc) consists of quartz sands, dolostones and clays. The unit ranges in color from greenish-gray and light gray to olive gray. The most common lithology in the upper section of the unit is characteristically a sandy to very sandy dolostone which may be interbedded with quartz sands and clays (Scott, 1988). Quartz sands and clays dominate and dolostones become subordinate in the lower portion of the section. The quartz sands are fine- to medium-grained, generally phosphatic, clayey and dolomitic. In many instances, the sands grade into dolostones and clays. Clay content is variable and may range from five to more than 30 percent (Scott, 1988). Phosphate content is highly variable, ranging from a trace to more than 20 percent. Coarse phosphate sands and pebbles are present but not common in the unit. The unit is unconformably overlain by undifferentiated Pliocene/Pleistocene shelly sediments (TQsu) throughout most of the mapped area (OFMS 106, Plate 2). It is unconformably overlain by 
the Pliocene/Pleistocene Cypresshead Formation (TQc) and undifferentiated Quaternary sediments (Qu) in the vicinity of Trail Ridge where the TQsu sediments are missing (OFMS 106, Plate 2, cross-sections A-A' and B-B'). The Coosawhatchie Formation occurs throughout the mapped area, except in the southwestern corner where they grade into undifferentiated Hawthorn Group sediments (Th; OFMS 106, Plate 2). The top of the Coosawhatchie Formation ranges between 70 feet (21.3 meters) above MSL in W-15183 (OFMS 106; Plate 2, cross-section B-B') to 88 feet (26.8 meters) below MSL in W-13746 (OFMS 106; Plate 2, cross-section A-A'). The Coosawhatchie Formation ranges in thickness from 5 feet (1.5 meters) in well W-14354 (OFMS 106; Plate 2, cross-section D-D') to 125 feet (38.1 meters) in well W-13744 (OFMS 106; Plate 2, cross-section A-A').

Hawthorn Group (Undifferentiated)

The Coosawhatchie, Marks Head and Penney Farms formations often become difficult to break out lithologically, especially in cuttings, in the areas between the Sanford High and the Peninsular Arch. In these cases, the sediments are mapped as undifferentiated Hawthorn Group (Th; Scott, 1988). There are a few wells in the very southwestern portion of the study area where the formations of the Hawthorn Group could not be reliably differentiated (OFMS 106, Plate 2; cross-section C-C', W-18527).

Where exposed, west of the mapped area, the undifferentiated Hawthorn Group is light olive gray and blue gray in unweathered sections and reddish-brown to reddish-gray in weathered sections (Green et al., 2009a). It consists of poorly to moderately-consolidated, clayey sands to silty clays and relatively pure clays with little-to-no phosphate due to leaching and transport (Scott, 2001). It is typically deeply weathered. Where present, the undifferentiated Hawthorn Group unconformably overlies the Ocala Limestone (Scott et al., 2001). It is unconformably overlain by undifferentiated Quaternary (Qu) sediments (OFMS 106, Plate 2; cross-section C-C', W-18527). There were not enough wells with undifferentiated Hawthorn Group sediments penetrated in the study area to give reliable estimates of thickness or elevation ranges for the unit.

Due to the karstic nature of the Central Lakes District, elevations of the Hawthorn Group are highly variable. Undifferentiated Hawthorn Group sediments are often clayey sands and only rarely consist of relatively pure clays. The Hawthorn Group generally has low permeability and forms part of the IAS/ICU (Southeastern Geological Society Ad Hoc Committee on Florida Hydrostratigraphic Unit Definition, 1986).

\section{Tertiary/Quaternary Systems}

\section{Pliocene/Pleistocene Series}

\section{Cypresshead Formation}

The Pliocene/Pleistocene Cypresshead Formation (TQc), named by Huddlestun (1988), is a mottled reddish-brown to reddish-orange to white, unconsolidated to poorly consolidated, fineto very coarse-grained, variably clayey to clean quartz sand. Cross-beds are common within this formation. Discoid quartzite pebbles, mica, and ghosts of nearshore marine molluscs are often present. The Cypresshead Formation is present throughout part of the western and southern edges of the study area and forms the core of the Crescent City Ridge and Palatka Hill (OFMS 106, Plate 1 and Plate 3). East of the St. Johns River, it typically becomes a more weathered, finer-grained, 
well-sorted sand and silt. In cores, the unit is often characterized by beds of fine grained, well sorted sand with thin layers of clay dispersed through the sand.

Elevations range from approximately 70 feet (21.3 meters) above MSL to over 100 feet (30.5 meters) above MSL in the northwestern corner of the mapped area. The Cypresshead Formation thickness ranges between 10 feet (3.1 meters) to 100 feet (30.5 meters) in study area wells.

These sediments sit unconformably on the Coosawhatchie Formation (Hawthorn Group; Thc) in the vicinity of the Trail Ridge terrane (OFMS 106; Plates 2 and 3). Permeable sediments of the Cypresshead Formation form part of the surficial aquifer system (SAS; Southeastern Geological Society Ad Hoc Committee on Florida Hydrostratigraphic Unit Definition, 1986).

\section{Pliocene/Pleistocene Shelly Sediments}

A sequence of undifferentiated Pliocene/Pleistocene shelly sediments lies east of Trail Ridge. Huddlestun (1988) named this unit the Nashua Formation. Much of the evidence listed by Huddlestun (1988) was based on biostratigraphic correlation and not lithologic distinction. Efforts were made by the authors to locate the type section of the Nashua Formation, as defined by Huddlestun (1988), but it was inundated. Three cores were drilled in the Big Horse Aggregates pit in an attempt to determine the lithology of the unit. In these cores, the lithology of the unit was found to be highly variable even over short distances. As a result of the lithologic variability of the unit, the use of biostratigraphic correlation of Huddleston (1988) and minimal field exposures, these authors have decided to utilize the convention of the Scott et al. (2001) and map these sediments as undifferentiated Pliocene/Pleistocene shelly sediments (TQsu). While not a formally recognized lithostratigraphic unit, TQsu are mapped following the convention of Scott et al., (2001) in order to facilitate a better understanding of Florida's geology. The unit sits unconformably on the Coosawhatchie Formation of the Hawthorn Group (OFMS 106; Plate 2, cross-sections A-A', B-B', D-D' and E-E'). Huddlestun (1988) indicated that the unit grades laterally into the Cypresshead Formation (TQc) in the vicinity of the Trail Ridge. Evidence from this study and Green et al., (2013a, 2013b), however, indicates that the unit is, at least in part, older than the Cypresshead Formation in the vicinity of Crescent City Ridge. This may be a result of prograding of Cypresshead Formation sediments over TQsu marine sediments during changes in sea level. Work underway at the Florida Museum of Natural History indicates that some of these shelly sands are Pliocene (Roger Portell, personal communication). These undifferentiated shelly sands are overlain by the Cypresshead Formation in the Crescent City and DeLand ridges just south of the current study area (Green et al., 2013a, 2013b). Elsewhere, the unit is unconformably overlain by undifferentiated Quaternary sediments $(\mathrm{Qu})$, Quaternary beach ridge and dune sediments (Qbd), Holocene sediments (Qh), or the Anastasia Formation (Qa; OFMS 106, Plate 2).

Undifferentiated Pliocene/Pleistocene shelly sediments (TQsu) typically consist of fine-tomedium quartz sand with variable amounts of calcilutite, shell and clay. Shells, which may be very weathered, vary from whole to fragments and may occasionally become the dominant lithology. Other accessory minerals may include calcite, aragonite, clay, mica, heavy minerals and minor phosphate. Colors range from light gray to light olive gray.

The top of the undifferentiated Pliocene/Pleistocene shelly sediments ranges from 24 feet (7.3 meters) above MSL in W-14521, (OFMS 106; Plate 2, cross-section D-D') to 70 feet (21.3 meters) below MSL in W-18283 (OFMS 106; Plate 2, cross-section D-D'). The thickness of the undifferentiated Pliocene/Pleistocene shelly sediments in the cross-section wells varies from 10 
feet (3.1 meters) in W-14354 (OFMS 106; Plate 2, cross-sections B-B' and D-D') to 95 feet (28.9 meters) in W-18254 (OFMS 106; Plate 2, cross-section D-D'). Permeable sediments of the undifferentiated Pliocene/Pleistocene shelly sediments form part of the SAS (Southeastern Geological Society Ad Hoc Committee on Florida Hydrostratigraphic Unit Definition, 1986).

\section{Tertiary/Quaternary Dunes}

Tertiary/Quaternary dunes (TQd), while not a formally recognized lithostratigraphic unit, are mapped following the convention of Scott et al. (2001). Where LiDAR is available these dunes are readily differentiated from other units by their distinct topographic expression. These dune sediments are fine-to-medium quartz sand with varying amounts of disseminated organic matter. They are generally found at elevations above 100 feet (30.5 meters) MSL, although there are areas along the western flanks of the Trail Ridge sediments (Qtr) where elevations of these dune sands can be lower. Sands forming these dunes are thought to be derived from re-working of sediments from the Cypresshead Formation (TQc) and undifferentiated Quaternary sediments (Qu; OFMS 106, Plate 1). These sediments are considered part of the SAS (Southeastern Geological Society Ad Hoc Committee on Florida Hydrostratigraphic Unit Definition, 1986).

\section{Pleistocene to Holocene Series}

\section{Anastasia Formation}

The Anastasia Formation (Qa) is present within the Atlantic Coastal Complex in a narrow band along the eastern edge of the study area. The formation, named by Sellards (1912), is composed of interbedded coquinoid limestone and quartz sands. It typically occurs as an orangishbrown to very pale orange, unconsolidated to moderately indurated coquina consisting of whole and broken mollusc shells in a quartz sand matrix. The coquina is commonly cemented by sparry calcite. The sands occur as light gray to tan and orangish-brown, unconsolidated to moderately indurated, unfossiliferous to very fossiliferous beds. The unit sits unconformably on undifferentiated Pliocene/Pleistocene shelly sediments (TQsu; OFMS 106, Plate 2, cross-section E-E'). The top of the Anastasia Formation ranges from 5 feet (1.5 meters) above MSL (OFMS 106; Plate 2, cross-section E-E', W-15282), to near MSL (OFMS 106; Plate 2, cross-section E-E'). The thickness of the Anastasia Formation in the cross-section wells varies from 20 feet (6.1 meters) in W-19458 to 38 feet (11.6 meters) in W-15282 (OFMS 106; Plate 2, cross-section E-E'). This formation is considered part of the SAS (Southeastern Geological Society Ad Hoc Committee on Florida Hydrostratigraphic Unit Definition, 1986).

\section{Undifferentiated Quaternary Sediments}

Undifferentiated Quaternary sediments $(\mathrm{Qu})$ in the study area lie unconformably on the Hawthorn Group, undifferentiated Pliocene/Pleistocene shelly sediments or Cypresshead Formation (OFMS 106, Plate 2). While not a formally recognized lithostratigraphic unit, Qu are mapped following the convention of Scott et al., (2001) in order to facilitate a better understanding of Florida's geology. The undifferentiated Quaternary sediments present in the mapped area may be highly variable in thickness. Generally, these undifferentiated Quaternary sediments consist of white to gray to orange to blue-green, fine- to coarse-grained, clean to clayey unfossiliferous sands, 
sandy clays and clays with variable admixtures of organics. The undifferentiated Quaternary sediments form part of the SAS (Southeastern Geological Society Ad Hoc Committee on Florida Hydrostratigraphic Unit Definition, 1986).

\section{Quaternary Trail Ridge Sands}

Sediments mapped as Quaternary Trail Ridge Sands (Qtr) include heavy-mineral bearing sediments associated with Trail Ridge, but are not limited to just the ridge itself. They also include sediments of the Baywood Promontory of Pirkle et al., (1970). While not a formally recognized lithostratigraphic unit, they are mapped following the convention of Scott et al., (2001) in order to facilitate a better understanding of Florida's geology. These sediments consist of white to tan, medium to fine quartz beach ridge sands, unconsolidated to slightly indurated. They contain an average of three percent heavy minerals in some areas, of which approximately 45 percent are titanium-rich minerals consisting of ilmenite, luecoxene, and rutile. Other common heavy minerals in the unit include staurolite, zircon, kyanite, sillimanite, corundum, topaz, and tourmaline.

\section{Quaternary Beach Ridge and Dune}

Quaternary beach ridge and dune sediments (Qbd) are a subdivision of the undifferentiated Quaternary sediments that are noted on the basis of surficial expression of relict beach ridges and dunes. While not a formally recognized lithostratigraphic unit, Qbd are mapped following the convention of Scott et al., (2001) in order to facilitate a better understanding of Florida's geology. This unit unconformably overlies undifferentiated Pliocene/Pleistocene shelly sediments (TQsu), or the Anastasia Formation (Qa) in the eastern part of the study area (OFMS 106; Plates 1 and 2).

Beach ridge and dune sediments are dominantly siliciclastic sands and are unconsolidated to poorly consolidated. Organics typically occur as disseminated organic matrix, roots and plant debris, carbonized remains or charcoal. The unit is considered part of the SAS (Southeastern Geological Society Ad Hoc Committee on Florida Hydrostratigraphic Unit Definition, 1986).

\section{Holocene Sediments}

Sediments mapped as Holocene (Qh) may include quartz sands, marls, organics, humate, and minor carbonate sands and mud. They may also include fresh-water molluscs. Within the study area, they occur as modern barrier islands and floodplain deposits in the vicinity of Crescent Lake, the St. Johns and Ocklawaha Rivers and along the east coast. These sediments are considered part of the SAS (Southeastern Geological Society Ad Hoc Committee on Florida Hydrostratigraphic Unit Definition, 1986).

\section{HYDROGEOLOGY}

Hydrostratigraphic units within the map area, in ascending order, consist of the Floridan aquifer system (FAS), the Intermediate aquifer system/Intermediate confining unit (IAS/ICU), and the Surficial aquifer system (SAS; Southeastern Geological Society Ad Hoc Committee on Florida Hydrostratigraphic Unit Definition, 1986). The FAS, the primary source for springs and drinking water in the region, is generally comprised of carbonate units of the Avon Park Formation and the 
Ocala Limestone. The sands, silts, clays and carbonates of the Hawthorn Group comprise the IAS/ICU. The IAS/ICU is highly variable and in the study area. The SAS is comprised of the Cypresshead Formation, undifferentiated Pliocene/Pleistocene shelly sediments (TQsu), Tertiary/Quaternary dune sediments (TQd), undifferentiated Quaternary sediments (Qu), beach ridge and dune sediments (Qbd), and Holocene sediments (Qh).

Where clayey siliciclastic sediments of the Hawthorn Group and younger units are thick and continuous, they provide confinement for the FAS, but where the clayey siliciclastic sediments of the Hawthorn Group and younger units are thin, missing or lack significant clay component, karst features often occur. Several of these are found in the Crescent City and DeLand ridges.

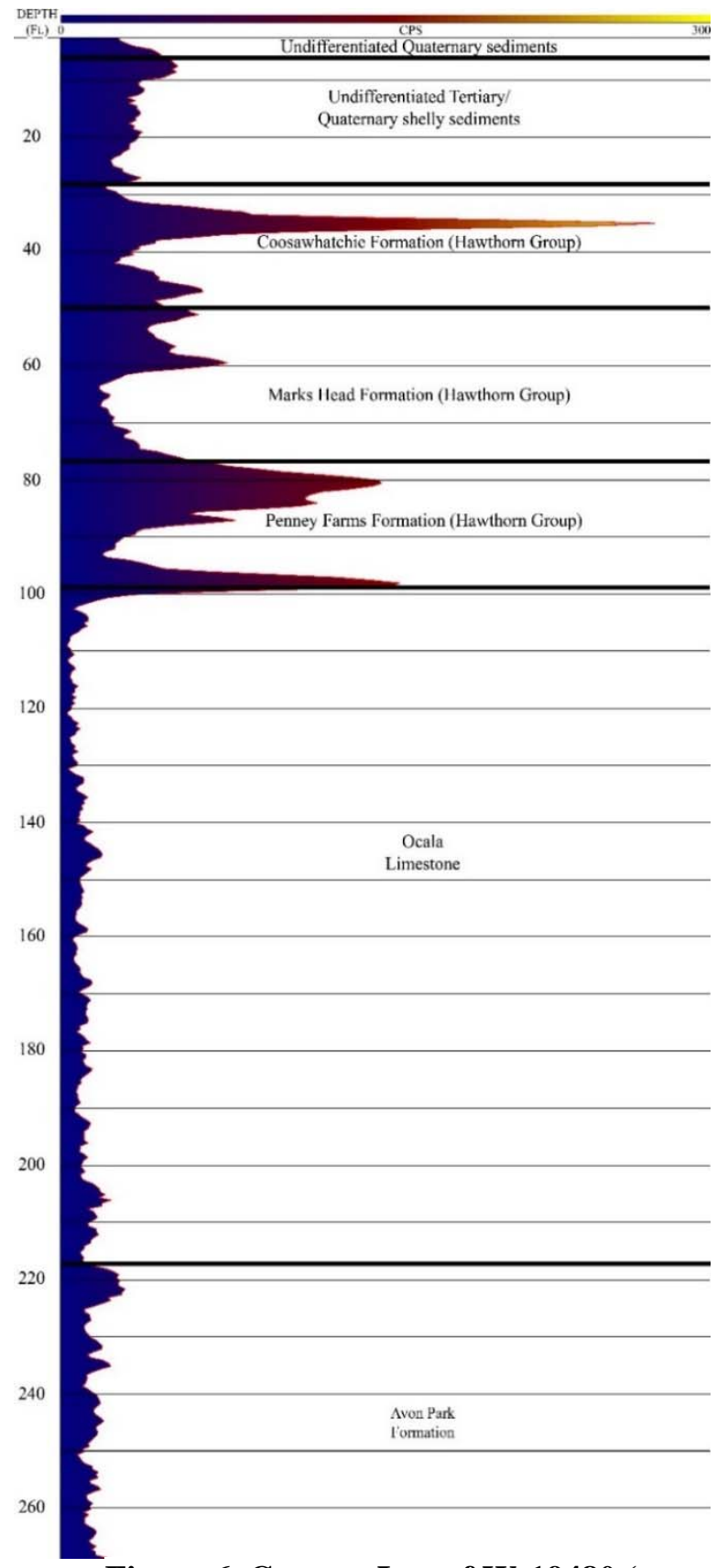

Figure 6. Gamma Log of W-19480 (see OFMS 106, plate 2, cross section B-B').

\section{GEOPHYSICAL LOGGING}

As part of this project, the St. Johns River Water Management District (SJRWMD) conducted geophysical logging on new wells drilled in the study area by the Florida Geological Survey. Boreholes were logged with a variety of geophysical tools, including Gamma (natural gamma log), Caliper, and Induction logs (Fluid Resistivity and Fluid Conductivity). The geophysical log of particular interest in this study was the gamma log for its usefulness in differentiating the various lithostratigraphic units by recording the naturally occurring gamma-ray activity in the lithology of the borehole wall.

By comparing gamma-ray activity between lithostratigraphic units it is often possible to differentiate them. This log is particularly useful for differentiating between Hawthorn Group units and subjacent and superjacent formations. Kwader (1982) and Scott (1988) discuss the gamma-ray response from clay minerals and phosphate typical to the formations in the Hawthorn Group. Development of high gamma activity occurs when minerals incorporate high percentages of potassium, uranium or thorium in their lattice structures. Potassium-rich sources include potassium feldspar, mica, and illitic clay. Uranium and thorium tend to be found in phosphorite, apatite, organic material and dolomite.

Gamma-ray intensity units were measured in counts per second (CPS). In Figure 6, gamma-ray intensity units are shown on the log horizontal axis in CPS for W-19480 (see OFMS 106, Plate 2, crosssection B-B'). Carbonates of the Ocala Limestone and Avon Park Formation have the lowest intensity 
gamma peaks in contrast to the high intensity radioactivity of the Hawthorn Group. Formations above the Hawthorn Group, such as the Cypresshead Formation and undifferentiated TertiaryQuaternary shelly sediments (TQsu), typically have much lower intensity signatures. In the study area, elevated radioactivity primarily results from the inclusion of phosphate grains. Medium intensity gamma-ray signatures are from moderately radioactive clay minerals and from organic material or peat (Davis et al., 2001).

\section{Stratigraphy and Gamma-Ray Log Interpretation}

\section{Avon Park Formation}

Logs from the Avon Park Formation typically show a combination of low gamma-ray intensity dolostone with distinct beds of relatively higher gamma-ray intensity lignite or organic layers. The top of the Avon Park Formation characteristically ranges from a yellow-gray dolomitic wackestone to a yellow-brown recrystallized dolostone. Below this initial lithology, but usually at or near the top of the unit, there can be variable amounts of black to dark brown, finely particulate to fibrous, partially decomposed organic material or lignite. The organic matter can occur as finely disseminated particles, sand to pebble sized blebs, identifiable leaf or sea-grass fossils, laminations or as discrete beds. The top of the Avon Park Formation is at approximately 218 feet (66.4 meters) below land surface (BLS) in W-19480 (see OFMS 106, Plate 2, crosssection $\left.\mathrm{B}-\mathrm{B}^{\prime}\right)$.

\section{Ocala Limestone}

In contrast to the higher intensity gamma-ray signature of the Hawthorn Group, the Ocala Limestone is easily identified on the gamma-ray log. This unit characteristically produces the lowest gamma-ray intensity in the Eocene stratigraphic sequence and can be used as a low baseline for relative gamma-ray intensity (Davis et al., 2001).

In general, the Ocala Limestone has lower gamma-ray intensity than the underlying Avon Park Formation. In the study area, however, dolomitization of the Avon Park Formation and recrystallization of the lowermost Ocala Limestone has significantly altered the original rock lithology and fabric making the distinction of the gamma-ray signatures between these units more difficult. The presence of organics when at or near the top of Avon Park Formation (e.g., Figure 6) can assist in determining the contact between these two formations. The contrast between the sediments of the lower Penney Farms Formation and upper Ocala Limestone generally makes this an easy break to pick out on gamma-ray logs (Figure 6).

Hawthorn Group

The Hawthorn Group consists of a complex sequence of siliciclastics and carbonates with varying percentages of phosphate minerals. The resulting gamma-ray peaks are, in general, significantly higher than those of the formations above and below the Hawthorn Group, which makes this unit easily discernible on geophysical logs (Figure 6).

The Hawthorn Group in the study area consists of the Penney Farms, Marks Head and Coosawhatchie formations. The gamma-ray logs from the cores drilled for this study show a pattern of three generalized zones corresponding with these formations. However, the pattern 
shows a variation in the intensities and thickness of peak groups dependent on the lithologic variation of the sample. For example, in W-19480 (OFMS 105; Plate 2, cross-section B-B') the higher gamma-ray intensity zones at approximately 27-50 feet (8.2-15.2 meters) BLS correlate with the Coosawhatchie Formation. The Coosawhatchie Formation in this well consists primarily of siliciclastics with varying amounts of dolomitic clay and fine to pebble sized phosphate ranging in content between 3 and 15 percent. The second zone is a lower intensity gamma-ray zone of the Marks Head Formation (between 50-76 feet [15.2-23.2 meters] BLS) consisting of a wellindurated, light gray recrystallized dolosilt with 1 to 3 percent fine-to-medium phosphate. The third zone correlates with the Penney Farms Formation 76-97.7 feet (23.2-29.8 meters). The gamma log of the Penny Farms Formation shows an upper, high gamma-ray intensity zone consisting of sands, clays and dolosilts with 7 to 30 percent phosphate, followed by a low gammaray intensity zone consisting of clays and dolosilts with low phosphate content. The base of the Penny Farms in this core consists of a thin, hard dolomite with 7 to 10 percent phosphate which is represented on the log by a high intensity spike.

The Penney Farms Formation in this core is highly variable in lithology and phosphate content as reflected in the gamma-ray log. The Penney Farms Formation unconformably overlies the Ocala Limestone. At this contact, the gamma-ray log intensity drops significantly and the delineation of these two formations is readily apparent (Figure 6).

Pliocene/Pleistocene shelly sediments

In the study area east of the St. Johns River, undifferentiated Pliocene/Pleistocene shelly sediments (TQsu) lie unconformably over the Hawthorn Group, and below the undifferentiated Quaternary sediments (OFMS 106, Plate 2). Undifferentiated Pliocene/Pleistocene shelly sediments present in the mapped area may be highly variable in thickness and typically consist of fine to medium quartz sand with variable amounts of calcilutite, shell, phosphate and clay. Other accessory minerals may include calcite, aragonite, clay, mica and heavy minerals. The presence of phosphate and heavy minerals can cause spikes in the gamma-ray log making this unit readily distinguishable from the underlying Coosawhatchie Formation (Hawthorn Group).

\section{DERIVATIVE PRODUCTS}

Several derivative products will come from this project. During the mapping project, data from approximately three hundred wells with samples were analyzed. Formation picks, made on all available wells with cores and cuttings samples, allow creation of a structure contour map of the top of the FAS, along with the construction of structure contour and isopach maps of the IAS/ICU in the area. Additional derivative data anticipated to come from this mapping effort include aquifer vulnerability assessment maps. Data derived from prior STATEMAP products have often been used to augment other Florida Geological Survey and Florida aquifer vulnerability assessment (FAVA) projects in the state (Arthur et al., 2007; Baker et al., 2007). 


\section{REFERENCES}

Alt, D., and Brooks, H.K., 1965, Age of the Florida marine terraces: Journal of Geology, v. 73, p. 406-411.

Applin, P., 1951, Possible future petroleum provinces of North America - Florida: American Association of Petroleum Geologists Bulletin, v. 35, p. 405-407.

Applin, P.L., and Applin, E.R., 1944, Regional subsurface stratigraphy and structure of Florida and southern Georgia: American Association of Petroleum Geologists Bulletin, v. 28, p. 16731753.

Arthur, J.D., Wood, H.A.R., Baker, A.E., Cichon, J.R., and Raines, G.L., 2007, Development and implementation of a Bayesian-based aquifer vulnerability assessment in Florida: Natural Resources Research, v. 16, p. 93-107.

Baker, A.E., Wood, H.A.R., and Cichon, J.R., 2007, The Marion County Aquifer Vulnerability Assessment: unpublished report submitted to Marion County Board of County Commissioners in fulfillment of Marion County Project No. SS06-01, March 2007, 42 p.

Bryan, J.R., 2004, Larger foraminifera: Introduction, biology, ecology, taxonomic and stratigraphic listings and comments on Florida fossil assemblages: Gainesville, Florida Paleontological Society, Florida Fossil Invertebrates, Part 6, 28 p.

Colquhoun, D.J., Johnson, G.H., Peebles, P.C., Huddlestun, P.F., and Scott, T., 1991, Quaternary geology of the Atlantic Coastal Plain, in Morrison, R.B., ed., Quaternary nonglacial geology; Conterminous U.S.: Boulder, Geological Society of America, The Geology of North America, v. K-2, p. 629-650.

Cooke, C.W., 1931, Seven coastal terraces in the southeastern United States: Washington Academy of Sciences Journal, v. 21, p. 503-513.

, 1939, Scenery of Florida interpreted by a geologist: Florida Geological Survey Bulletin 17, 120 p.

, 1945, Geology of Florida: Florida Geological Survey Bulletin 29, 342 p.

Copeland, R., Doran, N.A., White, A.J., and Upchurch, S.B., 2009, Regional and statewide trends in Florida's spring and well groundwater quality (1991-2003): Florida Geological Survey Bulletin 69, 203 p.

Dall, W.H., and Harris, G.D., 1892, Correlation papers, Neocene: U.S. Geological Survey Bulletin 84, 349 p. 


\section{FLORIDA GEOLOGICAL SURVEY}

Davis, J., Johnson R.A., Boniol D. and Rupert, F., 2001, Guidebook to the correlation of geophysical well logs within the St. Johns River Water Management District: Florida Geological Survey Special Publication 50, 114 p.

Espenshade, G.H., and Spencer, C.W., 1963, Geologic features of phosphate deposits of northern peninsular Florida: United States Geological Survey Bulletin 1118, 115 p.

Flint, R.F., 1940, Pleistocene features of the Atlantic coastal plain: American Journal of Science, v. 238, p. 757-787.

, 1971, Glacial and Quaternary Geology: New York, John Wiley and Sons, Inc., 892 p.

Green, R.C., Evans, W.L., III, Paul , D.T., and Scott, T.M., 2005, Geologic map of the eastern portion of the USGS Gainesville 30 x 60 minute quadrangle, northern Florida: Florida Geological Survey Open-File Map Series 94, scale 1:100,000, 2 plates.

Green, R.C., Williams, C.P., Paul, D.T., Kromhout, C., and Scott, T.M., 2009a, Geologic map of the eastern portion of the USGS Ocala 30 x 60 minute quadrangle, north-central Florida: Florida Geological Survey Open-File Map Series 100, scale 1:100,000, 3 plates.

Green, R.C., Williams, C.P., Paul, D.T., Kromhout, C., and Scott, T.M., 2009b, Text to accompany geologic map of the eastern portion of the USGS Ocala 30 x 60 minute quadrangle, central Florida: Florida Geological Survey Open-File Report 93, 28 p.

Green, R.C., Evans, W.L. III, Bassett, S.W., and Hannon, L.M., 2013a, Geologic map of the USGS Daytona Beach 30 × 60 minute quadrangle, northeast Florida: Florida Geological Survey Open-File Map Series 105, scale 1:100,000, 3 plates.

Green, R.C., Evans, W.L. III, Bassett, S.W., and Hannon, L.M., 2013b, Text to accompany geologic map of the USGS Daytona Beach 30 × 60 minute quadrangle northeast Florida: Florida Geological Survey Open-File Report 101, 37p.

Healy, H.G., 1975, Terraces and shorelines of Florida: Florida Geological Survey Map Series 71, scale: 1:2,095,200.

Huddlestun, P.F., 1988, A revision of the lithostratigraphic units of the Coastal Plain of Georgia, the Miocene through Holocene: Georgia Geologic Survey Bulletin 104, 262 p.

Jones, G.W., Upchurch, S.B., and Champion, K.M., 1996, Origin of nitrate in groundwater discharging from Rainbow Springs, Marion County, Florida: Brooksville, Southwest Florida Water Management District Report, 155 p.

Kwader T., 1982, Interpretation of borehole geophysical logs in shallow carbonate environments and their application to ground water resources investigations [Ph.D. Thesis]: Florida State University, Tallahassee, 322 p. 
MacNeil, F.S., 1950, Pleistocene shorelines in Florida and Georgia: U.S. Geological Survey Professional Paper 221-F, p. 95-107.

Matson, G.C., and Sanford, S., 1913, Geology and groundwater of Florida: U.S. Geological Survey Water Supply Paper 319, 445 p.

Miller, J.A., 1986, Hydrogeologic framework of the Floridan aquifer system in Florida and in parts of Georgia, Alabama, and South Carolina: Regional Aquifer-System Analysis: U.S. Geological Survey Professional Paper 1403-B, 91 p., 33 plates.

Phelps, G.G., 1994, Hydrogeology, water quality and potential for contamination of the upper Floridan Aquifer in the Silver Springs Ground-Water Basin, central Marion County, Florida: U.S. Geological Survey Water-Resources Investigations Report 92-4159, 69 p.

, 2004, Chemistry of groundwater in the Silver Springs Basin, with an emphasis on nitrate: U.S. Geological Survey Scientific Investigations Report 2004-5144, 54 p.

Pirkle, E.C., Jr., Yoho, W.H., and Hendry, C.W., Jr., 1970, Ancient sea level stands in Florida: Florida Geological Survey Bulletin 52, 61 p.

Pirkle, W.A. 1971, The offset course of the St Johns River, Florida: Southeastern Geology, v. 13, P. 39-59.

Poucher, S., and Copeland, R., 2006, Speleological and karst glossary of Florida and the Caribbean: Gainesville, University Press of Florida, 196 p.

Puri, H.S., and Vernon, R.O., 1964, Summary of the geology of Florida and a guidebook to the classic exposures: Florida Geological Survey Special Publication 5, revised, 312 p.

Riggs, S.R., 1979a, Petrology of the Tertiary phosphorite system of Florida: Economic Geology, V. 74, p. 195-220.

1979b, Phosphorite sedimentation in Florida - a model phosphogenic system: Economic Geology, v. 74, p. 285-314.

Schmidt, W., 1984, Neogene stratigraphy and geologic history of the Apalachicola Embayment: Florida Geological Survey Bulletin 58, 146 p.

Scott, T.M., 1983, The Hawthorn Formation of Northeastern Florida - Part I: The geology of the Hawthorn Formation of Northeastern Florida: Florida Geological Survey Report of Investigation 94, $90 \mathrm{p}$.

, 1988, The lithostratigraphy of the Hawthorn Group (Miocene) of Florida: Florida Geological Survey Bulletin 59, 148 p. 
, 1991, A geological overview, in Scott, T.M., Lloyd, J.M., and Maddox, G.L., eds., Florida's ground-water quality monitoring program, hydrogeologic framework: Florida Geological Survey Special Publication 32, 97 p.

, 1992a, Geologic map of Clay County, Florida: Florida Geological Survey Open-File Map Series 5, scale 1:126,720.

, 1992b, Geologic map of Flagler County, Florida: Florida Geological Survey OpenFile Map Series 7, scale 1:126,720.

, 1992c, Geologic map of Marion County, Florida: Florida Geological Survey OpenFile Map Series 13, scale 1:126,720.

, 1992d, Geologic map of Putnam County, Florida: Florida Geological Survey OpenFile Map Series 6, scale 1:126,720.

, 1992e, Geologic map of St. Johns County, Florida: Florida Geological Survey OpenFile Map Series 68, scale 1:126,720.

, 1997, Miocene to Holocene history of Florida, in Randazzo, A.F. and Jones, D.S., eds., The geology of Florida: Gainesville, University Press of Florida, p. 57-67.

, 2001, Text to accompany the geologic map of Florida: Florida Geological Survey Open-File Report 80, 29 p.

Scott, T.M., Campbell, K.M., Rupert, F.R., Arthur, J.A., Green, R.C., Means, G.H., Missimer, T.M., Lloyd, J.M., and Duncan, J.G., 2001, Geologic map of Florida: Florida Geological Survey Map Series 146, scale 1:750,000.

Scott, T.M., Means, G.H., Means, R.C., and Meegan R.P., 2002, First magnitude springs of Florida: Florida Geological Survey Open-File Report 85, 138 p.

Scott, T.M., Paul, D.T., Means, G.H., and Williams, C.P. (in preparation), Geomorphic map of Florida: Florida Geological Survey, scale 1:750,000.

Sellards, E.H., 1912, The soils and other surface residual materials of Florida: Florida Geological Survey Fourth Annual Report, p. 1-79.

Sinclair, W.C., and Stewart, J.W., 1985, Sinkhole type, development, and distribution in Florida: Florida Geological Survey Map Series 110, scale 30 miles to 1 inch.

Southeastern Geological Society Ad Hoc Committee on Florida Hydrostratigraphic Unit Definition, 1986, Hydrogeological units of Florida: Florida Geological Survey Special Publication 28, 8 p. 
Upchurch, S.B., Champion, K.M., Schneider, J.C., Hornsby, D., Ceryak, R., and Zwanka, W., 2004, Defining springshed boundaries and water-quality domains near first-magnitude springs in north Florida [abstract]: Florida Scientist, v. 67, Supplement 1, p. 52

U.S. Geological Survey, 1979, 1:100,000-scale metric topographic map of Saint Augustine, Florida: Reston, U.S. Geological Survey, 1 sheet.

Vernon, R.O., 1951a, Geology of Citrus and Levy Counties, Florida: Florida Geological Survey Bulletin 33, 256 p.

Vernon, R.O., 1951b, Surface occurrences of geologic formations in Florida (geologic map): Florida Geological Survey Map Series 3, 1 sheet, scale approximately 48 miles to 1 inch.

Waltham, T., Bell, F., and Culshaw, M., 2005, Sinkholes and subsidence, karst and cavernous rocks in engineering and construction: Chichester, Praxis Publishing Ltd., 382 p.

White, W.A., 1970, The geomorphology of the Florida peninsula: Florida Geological Survey Bulletin 51, $164 \mathrm{p}$.

Williams, K.E. Dodd, K., and Randazzo, A.F., 1977, The geology of the western part of Alachua County, Florida: Florida Geological Survey Report of Investigations 85, 98 p.

Williams, C.P., Cichon, J.R., Hartman, L.M., and Apolinar, B., 2014 (in review), Geomorphology and geology of selected coastal regions in northeastern Florida: Florida Geological Survey.

\section{ACKNOWLEDGEMENTS}

The authors extend many thanks to the personnel that assisted with access to land holdings: Donna Watkins with the Florida Department of Environmental Protection's Division of Recreation and Parks expedited the permit process for rock sample collection in Florida State Parks. Kurt Foote, Andrew Rich and Melissa Schmidt at Fort Matanzas National Monument kindly provided assistance when on site. Many thanks also go to our Department of Environmental Protection partners in the State Parks. Paul Crawford and Renee Paolini provided access to Fort Mose Historic State Park, Anastasia State Park, Faver-Dykes State Park and Washington Oaks Gardens State Park. Renee Paolini was very gracious to allow collection of a core at Faver-Dykes State Park and to permit staff to take us out in boats on the Intracoastal Waterway and to Faver-Dykes Islands on several occasions to assess outcrops of the Anastasia Formation.

Steven R. Miller with the St. Johns River Water Management's (SJRWMD) Bureau of Land Management was instrumental in granting the Special Use Authorization that allowed the FGS access for field reconnaissance and drilling on SJRWMD properties. Don Boniol (SJRWMD) is thanked for help in verifying well information. Christine Mundy and Jill Andrea (SJRWMD) provided assistance with Putnam County LiDAR data. We would also bestow a special thanks to Jeff Davis with the SJRWMD Bureau of Groundwater Sciences for sharing his knowledge and experience on the overall geology and geophysical data within the study area as well as sponsoring the 2013 State Mapping Advisory Committee (SMAC) meeting in Palatka Florida. Discussions with Roger Portell, the Director of Invertebrate Paleontology at the Florida Museum of Natural 


\section{FLORIDA GEOLOGICAL SURVEY}

History, were helpful in establishing the age correlation of some of the Tertiary/Quaternary units within the study area. The FGS STATEMAP staff would like to thank Mr. Carl Salafrio of Big Horse Aggregates LLC, for allowing access to the property.

Brianne Apolinar, Seth Bassett, Phil Bambach, Ken Campbell, Bob Cleveland, Levi Hannon, Jesse Hurd, Guy Richardson, and Eric Thomas provided field support for drilling operations. Tyler Weinand of the St. Johns River Water Management District provided geophysical logging for the new cores collected in the study area. Levi Hannon, Alan Baker, Seth Bassett and James Cichon worked to make sure all wells were appropriately located using every piece of archived well location information that could be found. Thank you to Frank Rupert, Jackie Lloyd, and Harley Means who reviewed, discussed and edited the product. Tom Scott continues to be an asset to geologic mapping in Florida and the ongoing work to revise the state's geomorphic map. This geologic map was funded in part by the Office of the Florida Geological Survey of the Florida Department of Environmental Protection and by the United States Geological Survey National Cooperative Geologic Mapping Program under assistance award number G13AC00318 in Federal fiscal year 2013. 


\section{APPENDIX A: FGS WELLS UTILIZED FOR STUDY}

This table lists FGS wells within the boundaries of the USGS Saint Augustine 30 x 60 minute quadrangle utilized for the top of rock model and/or geologic mapping. Due to graphical constraints, not all wells will appear on Plate 1 of OFMS 106. The first 38 wells in the table were utilized for geologic cross-sections and appear on Plates 1 and 2 of OFMS 106.

\begin{tabular}{|c|c|c|c|c|c|c|c|c|}
\hline $\begin{array}{c}\text { Map } \\
\text { ID }\end{array}$ & $\begin{array}{c}\text { Well } \\
\text { Label }\end{array}$ & $\begin{array}{c}\text { Data } \\
\text { Source }\end{array}$ & $\begin{array}{c}\text { Sample } \\
\text { Type }\end{array}$ & Latitude & Longitude & 24K Quad & $\begin{array}{c}\text { Elevation } \\
\text { (ft.) }\end{array}$ & $\begin{array}{c}\text { Total } \\
\text { Depth (ft.) }\end{array}$ \\
\hline 1 & W-533 & FGS & Cuttings & 29.97248 & -81.97971 & KINGSLEY & 163 & 658 \\
\hline 2 & W-537 & FGS & Cuttings & 29.93971 & -81.97947 & KINGSLEY & 189 & 580 \\
\hline 3 & W-3478 & FGS & Cuttings & 29.96917 & -81.69329 & GREEN COVE SPRINGS & 13 & 600 \\
\hline 4 & W-3901 & FGS & Cuttings & 29.71596 & -81.7193 & PALATKA & 8 & 600 \\
\hline 5 & W-4972 & FGS & Cuttings & 29.62191 & -81.89716 & KEUKA & 108 & 300 \\
\hline 6 & $\mathrm{~W}-8400$ & FGS & Core & 29.71351 & -81.84449 & BAYWOOD & 211 & 302 \\
\hline 7 & W-12339 & FGS & Cuttings & 29.53858 & -81.20673 & BEVERLY BEACH & 22 & 398 \\
\hline 8 & W-13744 & FGS & Core & 29.99413 & -81.50214 & PICOLATA & 27 & 252 \\
\hline 9 & W-13746 & FGS & Cuttings & 29.96734 & -81.30984 & SAINT AUGUSTINE & 13 & 240 \\
\hline 10 & W-13765 & FGS & Core & 29.98752 & -81.45545 & BAKERSVILLE & 30 & 242 \\
\hline 11 & W-13769 & FGS & Core & 29.98389 & -81.83417 & PENNEY FARMS & 95 & 319 \\
\hline 12 & W-13983 & FGS & Cuttings & 29.74468 & -81.63833 & PALATKA & 41 & 440 \\
\hline 13 & W-14301 & FGS & Core & 29.872 & -81.92028 & GOLD HEAD BRANCH & 164 & 252 \\
\hline 14 & W-14346 & FGS & Core & 29.73134 & -81.89679 & PUTNAM HALL & 89 & 179 \\
\hline 15 & W-14354 & FGS & Core & 29.66667 & -81.58334 & HASTINGS & 17 & 152 \\
\hline 16 & W-14476 & FGS & Core & 29.97615 & -81.72222 & GREEN COVE SPRINGS & 63 & 425 \\
\hline 17 & W-14521 & FGS & Core & 29.8459 & -81.65477 & BOSTWICK & 79 & 385 \\
\hline 18 & W-14566 & FGS & Core & 29.65831 & -81.88104 & PUTNAM HALL & 97 & 226 \\
\hline 19 & W-14886 & FGS & Cuttings & 29.81454 & -81.30592 & SAINT AUGUSTINE BEACH & 18 & 110 \\
\hline 20 & W-15183 & FGS & Cuttings & 29.72542 & -81.95459 & PUTNAM HALL & 133 & 350 \\
\hline 21 & W-15253 & FGS & Cuttings & 29.97738 & -81.39648 & BAKERSVILLE & 34 & 280 \\
\hline 22 & W-15282 & FGS & Core & 29.63722 & -81.21083 & MATANZAS INLET & 6 & 462 \\
\hline 23 & W-16216 & FGS & Cuttings & 29.85444 & -81.2896 & SAINT AUGUSTINE BEACH & 9 & 240 \\
\hline 24 & W-17173 & FGS & Cuttings & 29.53528 & -81.5875 & SAN MATEO & 45 & 200 \\
\hline 25 & W-18254 & FGS & Cuttings & 29.87278 & -81.65972 & BOSTWICK & 66 & 390 \\
\hline 26 & W-18283 & FGS & Cuttings & 29.94028 & -81.68584 & GREEN COVE SPRINGS & 45 & 440 \\
\hline 27 & W-18527 & FGS & Cuttings & 29.5175 & -81.9325 & KEUKA & 33 & 230 \\
\hline 28 & W-18532 & FGS & Cuttings & 29.58972 & -81.57611 & SAN MATEO & 21 & 260 \\
\hline 29 & W-18534 & FGS & Cuttings & 29.87361 & -81.28278 & SAINT AUGUSTINE BEACH & 9 & 95 \\
\hline 30 & W-18580 & FGS & Core & 29.71579 & -81.23597 & MATANZAS INLET & 3 & 500 \\
\hline 31 & W-18819 & FGS & Cuttings & 29.97806 & -81.86305 & PENNEY FARMS & 91 & 420 \\
\hline 32 & W-19434 & FGS & Core & 29.75528 & -81.31194 & SAINT AUGUSTINE BEACH & 27 & 181 \\
\hline 33 & W-19435 & FGS & Core & 29.69278 & -81.45 & SPUDS & 22 & 180 \\
\hline 34 & W-19450 & FGS & Core & 29.71363 & -81.30077 & DINNER ISLAND NE & 24 & 200 \\
\hline 35 & W-19458 & FGS & Core & 29.87361 & -81.28278 & SAINT AUGUSTINE BEACH & 9 & 700 \\
\hline 36 & W-19473 & FGS & Core & 29.6847 & -81.25121 & DINNER ISLAND NE & 12 & 416 \\
\hline 37 & W-19480 & FGS & Core & 29.68281 & -81.52512 & HASTINGS & 12 & 310 \\
\hline 38 & W-19488 & FGS & Core & 29.6925 & -81.4503 & SPUDS & 24 & 193.5 \\
\hline 39 & $\mathrm{~W}-136$ & FGS & Cuttings & 29.97673 & -81.81301 & PENNEY FARMS & 97 & 550 \\
\hline 40 & W-145 & FGS & Cuttings & 29.99344 & -81.54733 & PICOLATA & 17 & 436 \\
\hline 41 & W-152 & FGS & Cuttings & 29.66945 & -81.49583 & SPUDS & 16 & 320 \\
\hline 42 & W-179 & FGS & Cuttings & 29.53888 & -81.84177 & RODMAN & 24 & 75 \\
\hline 43 & W-236 & FGS & Cuttings & 29.89278 & -81.31583 & SAINT AUGUSTINE & 5 & 1440 \\
\hline 44 & W-237 & FGS & Cuttings & 29.89226 & -81.31522 & SAINT AUGUSTINE & 5 & 265 \\
\hline 45 & W-321 & FGS & Cuttings & 29.82159 & -81.9535 & GOLD HEAD BRANCH & 123 & 202 \\
\hline 46 & W-353 & FGS & Cuttings & 29.82159 & -81.9535 & GOLD HEAD BRANCH & 149 & 181 \\
\hline 47 & W-482 & FGS & Cuttings & 29.97979 & -81.98806 & KINGSLEY & 185 & 290 \\
\hline 48 & W-512 & FGS & Cuttings & 29.97979 & -81.98806 & KINGSLEY & 188 & 522 \\
\hline 49 & W-534 & FGS & Cuttings & 29.96885 & -81.97136 & KINGSLEY & 153 & 700 \\
\hline 50 & W-535 & FGS & Cuttings & 29.96149 & -81.96296 & KINGSLEY & 153 & 680 \\
\hline 51 & W-536 & FGS & Cuttings & 29.9451 & -81.97314 & KINGSLEY & 164 & 581 \\
\hline 52 & W-538 & FGS & Cuttings & 29.93976 & -81.99635 & KINGSLEY & 221 & 718 \\
\hline 53 & W-539 & FGS & Cuttings & 29.93608 & -81.99212 & KINGSLEY & 198 & 695 \\
\hline 54 & W-540 & FGS & Cuttings & 29.96971 & -81.96407 & KINGSLEY & 151 & 685 \\
\hline 55 & W-613 & FGS & Cuttings & 29.85721 & -81.97256 & GOLD HEAD BRANCH & 213 & 560 \\
\hline
\end{tabular}


FLORIDA GEOLOGICAL SURVEY

\begin{tabular}{|c|c|c|c|c|c|c|c|c|}
\hline $\begin{array}{c}\text { Map } \\
\text { ID }\end{array}$ & $\begin{array}{c}\text { Well } \\
\text { Label }\end{array}$ & $\begin{array}{c}\text { Data } \\
\text { Source }\end{array}$ & $\begin{array}{c}\text { Sample } \\
\text { Type }\end{array}$ & Latitude & Longitude & 24K Quad & $\begin{array}{c}\text { Elevation } \\
\text { (ft.) }\end{array}$ & $\begin{array}{c}\text { Total } \\
\text { Depth (ft.) }\end{array}$ \\
\hline 56 & W-617 & FGS & Cuttings & 29.95968 & -81.9734 & KINGSLEY & 164 & 766 \\
\hline 57 & $\mathrm{~W}-867$ & FGS & Cuttings & 29.87197 & -81.34769 & SAINT AUGUSTINE BEACH & 34 & 115 \\
\hline 58 & W-1120 & FGS & Cuttings & 29.59847 & -81.6422 & SATSUMA & 0 & 21.1 \\
\hline 59 & W-1122 & FGS & Cuttings & 29.53229 & -81.68233 & SATSUMA & 26 & 45.1 \\
\hline 60 & W-1123 & FGS & Cuttings & 29.53229 & -81.68233 & SATSUMA & 26 & 116 \\
\hline 61 & W-1126 & FGS & Core & 29.504 & -81.91187 & KEUKA & 15 & 129 \\
\hline 62 & W-1127 & FGS & Core & 29.5065 & -81.91882 & KEUKA & 28 & 91 \\
\hline 63 & W-1440 & FGS & Cuttings & 29.55788 & -81.49823 & DINNER ISLAND & 19 & 1822 \\
\hline 64 & W-1480 & FGS & Cuttings & 29.59641 & -81.56889 & SAN MATEO & 36 & 150 \\
\hline 65 & W-1481 & FGS & Cuttings & 29.90694 & -81.49028 & BAKERSVILLE & 18 & 140 \\
\hline 66 & W-1488 & FGS & Cuttings & 29.53229 & -81.68233 & PALATKA & 12 & 230 \\
\hline 67 & W-1496 & FGS & Cuttings & 29.60197 & -81.56272 & SAN MATEO & 29 & 165 \\
\hline 68 & W-1498 & FGS & Cuttings & 29.62668 & -81.79722 & BAYWOOD & 79 & 190 \\
\hline 69 & W-1512 & FGS & Cuttings & 29.62214 & -81.58461 & HASTINGS & 17 & 155 \\
\hline 70 & W-1514 & FGS & Cuttings & 29.70478 & -81.74413 & BAYWOOD & 203 & 3328 \\
\hline 71 & W-1803 & FGS & Cuttings & 29.83883 & -81.97639 & GOLD HEAD BRANCH & 191 & 55 \\
\hline 72 & W-1804 & FGS & Cuttings & 29.65291 & -81.87064 & BAYWOOD & 112 & 65 \\
\hline 73 & W-1805 & FGS & Cuttings & 29.65291 & -81.87064 & BAYWOOD & 112 & 65 \\
\hline 74 & W-1806 & FGS & Cuttings & 29.65291 & -81.87064 & BAYWOOD & 112 & 65 \\
\hline 75 & W-1807 & FGS & Cuttings & 29.65291 & -81.87064 & BAYWOOD & 112 & 65 \\
\hline 76 & W-1838 & FGS & Cuttings & 29.53229 & -81.68233 & SATSUMA & 21 & 3892 \\
\hline 77 & W-2753 & FGS & Cuttings & 29.96917 & -81.69329 & GREEN COVE SPRINGS & 6 & 670 \\
\hline 78 & W-2898 & FGS & Cuttings & 29.94063 & -81.9827 & KINGSLEY & 220 & 757 \\
\hline 79 & W-2903 & FGS & Cuttings & 29.95413 & -81.96709 & KINGSLEY & 160 & 660 \\
\hline 80 & W-2907 & FGS & Cuttings & 29.99241 & -81.69998 & GREEN COVE SPRINGS & 25 & 600 \\
\hline 81 & W-3058 & FGS & Cuttings & 29.71589 & -81.51056 & HASTINGS & 7 & 110 \\
\hline 82 & W-3636 & FGS & Cuttings & 29.71376 & -81.73799 & PALATKA & 30 & 740 \\
\hline 83 & W-3748 & FGS & Cuttings & 29.71895 & -81.74018 & PALATKA & 18 & 740 \\
\hline 84 & W-3856 & FGS & Cuttings & 29.71265 & -81.70689 & PALATKA & 3 & 590 \\
\hline 85 & W-3902 & FGS & Cuttings & 29.73006 & -81.71116 & PALATKA & 11 & 600 \\
\hline 86 & W-3903 & FGS & Cuttings & 29.73353 & -81.71119 & PALATKA & 20 & 700 \\
\hline 87 & W-3954 & FGS & Cuttings & 29.50889 & -81.93667 & KEUKA & 62 & 85 \\
\hline 88 & W-3955 & FGS & Cuttings & 29.5062 & -81.93552 & KEUKA & 71 & 168 \\
\hline 89 & W-3980 & FGS & Cuttings & 29.71861 & -81.81506 & BAYWOOD & 124 & 266 \\
\hline 90 & W-4000 & FGS & Cuttings & 29.7276 & -81.75494 & PALATKA & 25 & 1000 \\
\hline 91 & W-4047 & FGS & Cuttings & 29.52307 & -82.02532 & KEUKA & 96 & 170 \\
\hline 92 & W-4060 & FGS & Cuttings & 29.50889 & -81.86667 & RODMAN & 114 & 142 \\
\hline 93 & W-4061 & FGS & Cuttings & 29.7096 & -81.58555 & HASTINGS & 16 & 148 \\
\hline 94 & W-4244 & FGS & Cuttings & 29.89899 & -81.35458 & SAINT AUGUSTINE & 36 & 60 \\
\hline 95 & W-4245 & FGS & Cuttings & 29.8988 & -81.35434 & SAINT AUGUSTINE & 38 & 60 \\
\hline 96 & W-4485 & FGS & Cuttings & 29.82545 & -81.97005 & GOLD HEAD BRANCH & 183 & 460 \\
\hline 97 & W-4978 & FGS & Cuttings & 29.62525 & -81.36975 & DINNER ISLAND NE & 38 & 622 \\
\hline 98 & W-5014 & FGS & Cuttings & 29.79933 & -81.45314 & ELKTON & 28 & 350 \\
\hline 99 & W-5019 & FGS & Cuttings & 29.56264 & -81.33388 & ESPANOLA & 46 & 112 \\
\hline 100 & W-5020 & FGS & Cuttings & 29.80552 & -81.5784 & RIVERDALE & 3 & 238 \\
\hline 101 & W-5022 & FGS & Cuttings & 29.62164 & -81.90967 & KEUKA & 127 & 533 \\
\hline 102 & W-5025 & FGS & Cuttings & 29.73006 & -81.63828 & PALATKA & 72 & 279 \\
\hline 103 & W-5026 & FGS & Cuttings & 29.64064 & -81.7043 & PALATKA & 69 & 256 \\
\hline 104 & W-5027 & FGS & Cuttings & 29.71198 & -81.82134 & BAYWOOD & 126 & 266 \\
\hline 105 & W-5028 & FGS & Cuttings & 29.65668 & -81.57639 & HASTINGS & 16 & 547 \\
\hline 106 & W-5030 & FGS & Cuttings & 29.53229 & -81.68233 & SATSUMA & 28 & 66 \\
\hline 107 & W-5032 & FGS & Cuttings & 29.72709 & -81.47749 & SPUDS & 15 & 414 \\
\hline 108 & W-5033 & FGS & Cuttings & 29.50848 & -81.49507 & SAN MATEO & 0 & 100 \\
\hline 109 & W-5035 & FGS & Cuttings & 29.56053 & -81.16784 & BEVERLY BEACH & 1 & 152 \\
\hline 110 & W-5036 & FGS & Cuttings & 29.51608 & -81.39743 & DINNER ISLAND & 0 & 167.5 \\
\hline 111 & W-5041 & FGS & Cuttings & 29.55944 & -81.26792 & ESPANOLA & 36 & 136 \\
\hline 112 & W-5042 & FGS & Cuttings & 29.94068 & -81.48501 & BAKERSVILLE & 22 & 412.3 \\
\hline 113 & W-5043 & FGS & Cuttings & 29.73489 & -81.99439 & PUTNAM HALL & 107 & 131 \\
\hline 114 & W-5162 & FGS & Cuttings & 29.8216 & -81.99085 & GOLD HEAD BRANCH & 171 & 39 \\
\hline 115 & W-5164 & FGS & Cuttings & 29.7818 & -81.94888 & GOLD HEAD BRANCH & 95 & 25 \\
\hline 116 & W-5166 & FGS & Cuttings & 29.74924 & -81.98199 & PUTNAM HALL & 117 & 39 \\
\hline 117 & W-5168 & FGS & Cuttings & 29.84461 & -81.92037 & GOLD HEAD BRANCH & 150 & 14 \\
\hline 118 & W-5172 & FGS & Cuttings & 29.98001 & -81.92097 & KINGSLEY & 150 & 16 \\
\hline 119 & W-5173 & FGS & Cuttings & 29.9767 & -81.86204 & PENNEY FARMS & 91 & 24 \\
\hline
\end{tabular}


OPEN-FILE REPORT 102

\begin{tabular}{|c|c|c|c|c|c|c|c|c|}
\hline $\begin{array}{c}\text { Map } \\
\text { ID }\end{array}$ & $\begin{array}{c}\text { Well } \\
\text { Label }\end{array}$ & $\begin{array}{c}\text { Data } \\
\text { Source }\end{array}$ & $\begin{array}{c}\text { Sample } \\
\text { Type }\end{array}$ & Latitude & Longitude & 24K Quad & $\begin{array}{c}\text { Elevation } \\
\text { (ft.) }\end{array}$ & $\begin{array}{c}\text { Total } \\
\text { Depth (ft.) }\end{array}$ \\
\hline 120 & W-5174 & FGS & Cuttings & 29.85915 & -81.94563 & GOLD HEAD BRANCH & 206 & 38 \\
\hline 121 & W-5175 & FGS & Cuttings & 29.89942 & -81.89966 & KINGSLEY & 111 & 16 \\
\hline 122 & W-5176 & FGS & Cuttings & 29.92506 & -81.89542 & KINGSLEY & 92 & 18 \\
\hline 123 & W-5179 & FGS & Cuttings & 29.77446 & -81.98215 & GOLD HEAD BRANCH & 135 & 44 \\
\hline 124 & W-5321 & FGS & Cuttings & 29.77444 & -81.98628 & GOLD HEAD BRANCH & 116 & 249 \\
\hline 125 & W-5347 & FGS & Cuttings & 29.86849 & -81.7812 & RICE CREEK & 100 & 319 \\
\hline 126 & W-5627 & FGS & Cuttings & 29.60683 & -81.99679 & KEUKA & 82 & 150 \\
\hline 127 & W-5959 & FGS & Cuttings & 29.62214 & -81.58461 & SAN MATEO & 22 & 126 \\
\hline 128 & W-5963 & FGS & Cuttings & 29.65462 & -81.66468 & PALATKA & 31 & 210 \\
\hline 129 & $\mathrm{~W}-6452$ & FGS & Cuttings & 29.756 & -81.78818 & RICE CREEK & 88 & 1000 \\
\hline 130 & W-6549 & FGS & Cuttings & 29.75764 & -81.79815 & RICE CREEK & 92 & 1000 \\
\hline 131 & W-6568 & FGS & Cuttings & 29.75357 & -81.77286 & RICE CREEK & 36 & 171 \\
\hline 132 & W-6643 & FGS & Cuttings & 29.77252 & -81.7935 & RICE CREEK & 46 & 1404 \\
\hline 133 & W-6914 & FGS & Cuttings & 29.64185 & -81.60522 & HASTINGS & 11 & 249.5 \\
\hline 134 & W-7515 & FGS & Cuttings & 29.87851 & -81.46975 & BAKERSVILLE & 23 & 105 \\
\hline 135 & W-7873 & FGS & Cuttings & 29.50612 & -81.95194 & KEUKA & 45 & 100 \\
\hline 136 & W-7995 & FGS & Cuttings & 29.93188 & -81.75581 & PENNEY FARMS & 116 & 100 \\
\hline 137 & W-8498 & FGS & Cuttings & 29.62778 & -81.63177 & PALATKA & 16 & 415 \\
\hline 138 & W-10307 & FGS & Core & 29.5058 & -81.88453 & KEUKA & 15 & 130 \\
\hline 139 & W-10481 & FGS & Core & 29.87506 & -81.70526 & GREEN COVE SPRINGS & 91 & 108 \\
\hline 140 & W-10637 & FGS & Cuttings & 29.78233 & -81.30851 & SAINT AUGUSTINE BEACH & 26 & 755 \\
\hline 141 & W-10653 & FGS & Cuttings & 29.95274 & -81.40752 & BAKERSVILLE & 35 & 4850 \\
\hline 142 & W-10797 & FGS & Cuttings & 29.97622 & -81.70602 & GREEN COVE SPRINGS & 61 & 640 \\
\hline 143 & W-10947 & FGS & Cuttings & 29.97622 & -81.70602 & GREEN COVE SPRINGS & 64 & 1120 \\
\hline 144 & W-11044 & FGS & Cuttings & 29.97622 & -81.70602 & GREEN COVE SPRINGS & 64 & 1045 \\
\hline 145 & W-11084 & FGS & Cuttings & 29.8498 & -81.45296 & $\begin{array}{l}\text { ELKTON } \\
\end{array}$ & 28 & 4584 \\
\hline 146 & W-11326 & FGS & Cuttings & 29.59375 & -81.96951 & KEUKA & 80 & 160 \\
\hline 147 & W-11414 & FGS & Cuttings & 29.92056 & -81.33833 & SAINT AUGUSTINE & 3 & 300 \\
\hline 148 & W-11722 & FGS & Cuttings & 29.55056 & -81.25174 & ESPANOLA & 31 & 250 \\
\hline 149 & W-12382 & FGS & Cuttings & 29.55679 & -81.21758 & BEVERLY BEACH & 22 & 330 \\
\hline 150 & W-13351 & FGS & Cuttings & 29.96456 & -81.49072 & BAKERSVILLE & 23 & 250 \\
\hline 151 & W-13440 & FGS & Cuttings & 29.53602 & -81.2421 & BEVERLY BEACH & 28 & 86 \\
\hline 152 & W-13532 & FGS & Cuttings & 29.86696 & -81.32758 & SAINT AUGUSTINE BEACH & 31 & 65 \\
\hline 153 & W-13585 & FGS & Cuttings & 29.82444 & -81.32088 & SAINT AUGUSTINE BEACH & 9 & 58 \\
\hline 154 & W-13586 & FGS & Cuttings & 29.82441 & -81.32088 & SAINT AUGUSTINE BEACH & 9 & 58 \\
\hline 155 & W-13710 & FGS & Cuttings & 29.52415 & -81.71362 & SATSUMA & 18 & 3903 \\
\hline 156 & W-13844 & FGS & Core & 29.66917 & -81.25889 & DINNER ISLAND NE & 8 & 178 \\
\hline 157 & W-13984 & FGS & Cuttings & 29.74468 & -81.63833 & PALATKA & 41 & 440 \\
\hline 158 & W-14105 & FGS & Cuttings & 29.92008 & -81.41562 & BAKERSVILLE & 44 & 110 \\
\hline 159 & W-14306 & FGS & Cuttings & 29.5375 & -81.25222 & ESPANOLA & 28 & 134 \\
\hline 160 & W-14353 & FGS & Core & 29.51126 & -81.66266 & SATSUMA & 86 & 165 \\
\hline 161 & W-14376 & FGS & Core & 29.62214 & -81.58334 & SAN MATEO & 7 & 252 \\
\hline 162 & W-14393 & FGS & Cuttings & 29.67122 & -81.68794 & PALATKA & 1 & 300 \\
\hline 163 & W-14413 & FGS & Core & 29.79389 & -81.49389 & ELKTON & 20 & 258 \\
\hline 164 & W-14452 & FGS & Cuttings & 29.95035 & -81.38397 & BAKERSVILLE & 35 & 100 \\
\hline 165 & W-14453 & FGS & Cuttings & 29.96955 & -81.39217 & BAKERSVILLE & 37 & 100 \\
\hline 166 & W-14477 & FGS & Core & 29.77483 & -81.57153 & RIVERDALE & 13 & 237 \\
\hline 167 & W-14560 & FGS & Cuttings & 29.73006 & -81.63828 & PALATKA & 76 & 550 \\
\hline 168 & W-14964 & FGS & Cuttings & 29.51752 & -81.28121 & ESPANOLA & 28 & 305 \\
\hline 169 & W-14965 & FGS & Cuttings & 29.50321 & -81.29755 & ESPANOLA & 28 & 220 \\
\hline 170 & W-14966 & FGS & Cuttings & 29.51746 & -81.28114 & ESPANOLA & 28 & 220 \\
\hline 171 & W-14967 & FGS & Cuttings & 29.49992 & -81.27909 & BUNNELL & 27 & 220 \\
\hline 172 & W-14968 & FGS & Cuttings & 29.50411 & -81.2666 & ESPANOLA & 28 & 220 \\
\hline 173 & W-14971 & FGS & Cuttings & 29.56861 & -81.29529 & ESPANOLA & 31 & 100 \\
\hline 174 & W-14972 & FGS & Cuttings & 29.54918 & -81.27306 & ESPANOLA & 31 & 100 \\
\hline 175 & W-14973 & FGS & Cuttings & 29.55486 & -81.28152 & ESPANOLA & 31 & 100 \\
\hline 176 & W-14974 & FGS & Cuttings & 29.56706 & -81.27814 & ESPANOLA & 35 & 100 \\
\hline 177 & W-14975 & FGS & Cuttings & 29.56477 & -81.28375 & ESPANOLA & 31 & 90 \\
\hline 178 & W-14976 & FGS & Cuttings & 29.55486 & -81.28152 & ESPANOLA & 31 & 110 \\
\hline 179 & W-14977 & FGS & Cuttings & 29.54761 & -81.27753 & ESPANOLA & 28 & 100 \\
\hline 180 & W-14978 & FGS & Cuttings & 29.54742 & -81.26839 & ESPANOLA & 28 & 80 \\
\hline 181 & W-14979 & FGS & Cuttings & 29.54104 & -81.26643 & ESPANOLA & 28 & 100 \\
\hline 182 & W-14990 & FGS & Cuttings & 29.88054 & -81.42018 & BAKERSVILLE & 45 & 94 \\
\hline 183 & W-14997 & FGS & Cuttings & 29.87664 & -81.4241 & BAKERSVILLE & 40 & 95 \\
\hline
\end{tabular}


FLORIDA GEOLOGICAL SURVEY

\begin{tabular}{|c|c|c|c|c|c|c|c|c|}
\hline $\begin{array}{l}\text { Map } \\
\text { ID }\end{array}$ & $\begin{array}{c}\text { Well } \\
\text { Label }\end{array}$ & $\begin{array}{c}\text { Data } \\
\text { Source } \\
\end{array}$ & $\begin{array}{c}\text { Sample } \\
\text { Type }\end{array}$ & Latitude & Longitude & 24K Quad & $\begin{array}{c}\text { Elevation } \\
\text { (ft.) }\end{array}$ & $\begin{array}{c}\text { Total } \\
\text { Depth (ft.) }\end{array}$ \\
\hline 184 & W-15039 & FGS & Cuttings & $<$ Null $>$ & $<$ Null $>$ & PALATKA & 11 & 300 \\
\hline 185 & W-15254 & FGS & Cuttings & 29.98688 & -81.40313 & BAKERSVILLE & 33 & 120 \\
\hline 186 & W-15255 & FGS & Cuttings & 29.97572 & -81.39542 & BAKERSVILLE & 36 & 380 \\
\hline 187 & W-15256 & FGS & Cuttings & 29.95421 & -81.38528 & BAKERSVILLE & 38 & 105 \\
\hline 188 & W-15257 & FGS & Cuttings & 29.96205 & -81.38839 & BAKERSVILLE & 37 & 120 \\
\hline 189 & W-15258 & FGS & Cuttings & 29.95819 & -81.38648 & BAKERSVILLE & 37 & 100 \\
\hline 190 & W-15657 & FGS & Core & 29.53477 & -81.57167 & SAN MATEO & 0 & 96 \\
\hline 191 & W-16167 & FGS & Cuttings & 29.62357 & -81.90345 & KEUKA & 125 & 310 \\
\hline 192 & W-16168 & FGS & Cuttings & 29.92004 & -81.35806 & SAINT AUGUSTINE & 28 & 100 \\
\hline 193 & W-16176 & FGS & Cuttings & 29.77691 & -81.43435 & ELKTON & 34 & 160 \\
\hline 194 & W-16210 & FGS & Cuttings & 29.8896 & -81.63848 & GREEN COVE SPRINGS & 13 & 340 \\
\hline 195 & W-16220 & FGS & Cuttings & 29.82118 & -81.38541 & ELKTON & 42 & 100 \\
\hline 196 & W-16230 & FGS & Cuttings & 29.71806 & -81.50025 & HASTINGS & 1 & 180 \\
\hline 197 & W-16807 & FGS & Cuttings & 29.62959 & -81.53231 & HASTINGS & 25 & 400 \\
\hline 198 & W-17059 & FGS & Cuttings & 29.81972 & -81.95722 & GOLD HEAD BRANCH & 130 & 350 \\
\hline 199 & W-17152 & FGS & Cuttings & 29.70222 & -81.45834 & SPUDS & 19 & 245 \\
\hline 200 & W-17547 & FGS & Cuttings & 29.5175 & -81.75139 & RODMAN & 24 & 21.5 \\
\hline 201 & W-17611 & FGS & Core & 29.87387 & -81.41584 & ELKTON & 41 & 100 \\
\hline 202 & W-17698 & FGS & Cuttings & 29.77651 & -81.28619 & SAINT AUGUSTINE BEACH & 19 & 26 \\
\hline 203 & W-17699 & FGS & Cuttings & 29.77139 & -81.28472 & SAINT AUGUSTINE BEACH & 2 & 22 \\
\hline 204 & W-17784 & FGS & Cuttings & 29.63167 & -81.69195 & PALATKA & 59 & 146 \\
\hline 205 & W-17932 & FGS & Cuttings & 29.95917 & -81.61528 & PICOLATA & 7 & 201 \\
\hline 206 & W-18008 & FGS & Cuttings & 29.54389 & -81.72916 & SATSUMA & 27 & 51 \\
\hline 207 & W-18011 & FGS & Cuttings & 29.53555 & -81.55417 & SAN MATEO & 0 & 90 \\
\hline 208 & W-18016 & FGS & Cuttings & 29.95917 & -81.61528 & PICOLATA & 7 & 1177 \\
\hline 209 & W-18017 & FGS & Cuttings & 29.63194 & -81.69139 & PALATKA & 59 & 280 \\
\hline 210 & W-18177 & FGS & Cuttings & 29.87722 & -81.92694 & KINGSLEY & 170 & 187 \\
\hline 211 & W-18221 & FGS & Cuttings & 29.87722 & -81.92694 & KINGSLEY & 170 & 340 \\
\hline 212 & W-18275 & FGS & Cuttings & 29.83333 & -81.3575 & SAINT AUGUSTINE BEACH & 26 & 290 \\
\hline 213 & W-18280 & FGS & Cuttings & 29.56833 & -81.65222 & SATSUMA & 56 & 500 \\
\hline 214 & W-18294 & FGS & Cuttings & 29.83333 & -81.3575 & SAINT AUGUSTINE BEACH & 26 & 195 \\
\hline 215 & W-18382 & FGS & Cuttings & 29.93444 & -81.37639 & BAKERSVILLE & 36 & 800 \\
\hline 216 & W-18383 & FGS & Core & 29.7225 & -81.8225 & BAYWOOD & 158 & 200 \\
\hline 217 & W-18384 & FGS & Cuttings & 29.93444 & -81.37639 & BAKERSVILLE & 36 & 200 \\
\hline 218 & W-18385 & FGS & Cuttings & 29.80029 & -81.80793 & RICE CREEK & 87 & 125 \\
\hline 219 & W-18433 & FGS & Cuttings & 29.80445 & -81.80611 & RICE CREEK & 98 & 215 \\
\hline 220 & W-18483 & FGS & Cuttings & 29.54111 & -81.83139 & RODMAN & 24 & 210 \\
\hline 221 & W-18526 & FGS & Core & 29.50803 & -81.16203 & BEVERLY BEACH & 18 & 139 \\
\hline 222 & W-18528 & FGS & Core & 29.5175 & -81.9325 & KEUKA & 33 & 160 \\
\hline 223 & W-18530 & FGS & Core & 29.82389 & -81.55334 & RIVERDALE & 4 & 195 \\
\hline 224 & W-18531 & FGS & Cuttings & 29.82389 & -81.55334 & RIVERDALE & 4 & 260 \\
\hline 225 & W-18533 & FGS & Cuttings & 29.98417 & -81.56111 & PICOLATA & 16 & 211 \\
\hline 226 & W-18582 & FGS & Cuttings & 29.98416 & -81.56088 & PICOLATA & 16 & 340 \\
\hline 227 & W-18785 & FGS & Cuttings & 29.8742 & -81.41635 & ELKTON & 42 & 695 \\
\hline 228 & W-18786 & FGS & Cuttings & 29.8742 & -81.41635 & ELKTON & 42 & 450 \\
\hline 229 & W-18787 & FGS & Cuttings & 29.8742 & -81.41635 & ELKTON & 42 & 475 \\
\hline 230 & W-18788 & FGS & Cuttings & 29.97888 & -81.48952 & BAKERSVILLE & 27 & 750 \\
\hline 231 & W-18789 & FGS & Cuttings & 29.95738 & -81.52483 & PICOLATA & 12 & 475 \\
\hline 232 & W-18790 & FGS & Cuttings & 29.8804 & -81.41738 & BAKERSVILLE & 40 & 460 \\
\hline 233 & W-18791 & FGS & Cuttings & 29.89183 & -81.4226 & BAKERSVILLE & 40 & 455 \\
\hline 234 & W-18792 & FGS & Cuttings & 29.88085 & -81.40932 & BAKERSVILLE & 37 & 450 \\
\hline 235 & W-18793 & FGS & Cuttings & 29.88002 & -81.4251 & BAKERSVILLE & 40 & 455 \\
\hline 236 & W-18825 & FGS & Cuttings & 29.50805 & -81.16202 & BEVERLY BEACH & 18 & 290 \\
\hline 237 & W-19040 & FGS & Cuttings & 29.94363 & -81.38018 & BAKERSVILLE & 33 & 500 \\
\hline 238 & W-19042 & FGS & Cuttings & 29.88049 & -81.41846 & BAKERSVILLE & 42 & 425 \\
\hline 239 & W-19423 & FGS & Cuttings & 29.53722 & -81.20556 & BEVERLY BEACH & 20 & 144 \\
\hline 240 & W-19436 & FGS & Cuttings & 29.90722 & -81.49 & BAKERSVILLE & 16 & 201 \\
\hline 241 & W-19457 & FGS & Core & 29.6511 & -81.3219 & DINNER ISLAND NE & 29 & 340 \\
\hline
\end{tabular}

